\title{
How plant functional-type, weather, seasonal drought, and soil physical properties alter water and energy fluxes of an oak-grass savanna and an annual grassland
}

\author{
Dennis D. Baldocchi ${ }^{\mathrm{a}, *}$, Liukang Xu ${ }^{\mathrm{a}}$, Nancy Kiang ${ }^{\mathrm{b}}$ \\ ${ }^{a}$ Ecosystem Science Division, Department of Environmental Science, Policy and Management, 151 Hilgard Hall, \\ University of California, Berkeley, Berkeley, CA 94720, USA \\ ${ }^{\mathrm{b}}$ Center for Climate Systems Research, Columbia University, NASA Goddard Institute for Space Studies, \\ 2880 Broadway, New York, NY 10025, USA
}

Received 11 August 2003; received in revised form 28 October 2003; accepted 3 November 2003

\begin{abstract}
Savannas and open grasslands often co-exist in semi-arid regions. Questions that remain unanswered and are of interest to biometeorologists include: how do these contrasting landscapes affect the exchanges of energy on seasonal and annual time scales; and, do biophysical constraints imposed by water supply and water demand affect whether the land is occupied by open grasslands or savanna? To address these questions, and others, we examine how a number of abiotic, biotic and edaphic factors modulate water and energy flux densities over an oak-grass savanna and an annual grassland that coexist in the same climate but on soils with different hydraulic properties.

The net radiation balance was greater over the oak woodland than the grassland, despite the fact that both canopies received similar sums of incoming short and long wave radiation. The lower albedo and lower radiative surface temperature of the transpiring woodland caused it to intercept and retain more long and shortwave energy over the course of the year, and particularly during the summer dry period.

The partitioning of available energy into sensible and latent heat exchanged over the two canopies differed markedly. The annual sum of sensible heat exchange over the woodland was $40 \%$ greater than that over the grassland $\left(2.05 \mathrm{GJ} \mathrm{m}^{-2}\right.$ per year versus $1.46 \mathrm{GJ} \mathrm{m}^{-2}$ per year). With regards to evaporation, the oak woodland evaporated about $380 \mathrm{~mm}$ of water per year and the grassland evaporated about $300 \mathrm{~mm}$ per year. Differences in available energy, canopy roughness, the timing of physiological functioning, water holding capacity of the soil and rooting depth of the vegetation explained the observed differences in sensible and latent heat exchange of the contrasting vegetation surfaces.

The response of canopy evaporation to diminishing soil moisture was quantified by comparing normalized evaporation rates (in terms of equilibrium evaporation) with soil water potential and volumetric water content measurements. When soil moisture was ample normalized values of latent heat flux density were greater for the grassland (1.1-1.2) than for the oak savanna (0.7-0.8) and independent of moisture content. Normalized rates of evaporation over the grassland declined as volumetric water content dropped below $0.15 \mathrm{~m}^{3} \mathrm{~m}^{-3}$, which corresponded with a soil water potential of $-1.5 \mathrm{MPa}$. The grassland senesced and quit transpiring when the volumetric water content of the soil dropped below $-2.0 \mathrm{MPa}$. The oak trees, on the other hand, were able to transpire, albeit at low rates, under very dry soil conditions (soil water potentials below $-4.0 \mathrm{MPa}$ ). The trees were able to endure such low water potentials and maintain basal levels of metabolism because
\end{abstract}

\footnotetext{
* Corresponding author. Tel.: +1-510-642-2874; fax: 510-643-5098.
}

E-mail address: baldocchi@nature.berkeley.edu (D.D. Baldocchi). 
ecological forcings kept the tree density and leaf area index of the woodland low, physiological factors forced the stomata to close progressively and the trees were able to tap deeper water sources (below $0.6 \mathrm{~m}$ ) than the grasses.

(C) 2003 Elsevier B.V. All rights reserved.

Keywords: Ecohydrology; Evaporation; Biosphere-atmosphere interactions

\section{Introduction}

There are critical climate, soil and disturbance conditions that enable grass, trees or a mixture of trees and grass to dominate the composition of a landscape (Holdridge, 1947; Eagleson, 1982; Higgins et al., 2000; van Wijk and Rodriguez-Iturbe, 2002). Since trees and grass canopies differ in their ability to intercept and absorb photons and transpire (Kelliher et al., 1993; Miranda, 1997), their relative composition can have a profound effect on the surface energy balance of a landscape, which in turn, can have a modifying feedback on the regional climate (Zeng and Neelin, 2000) and its water balance (Joffre and Rambal, 1993; Rodriguez-Iturbe et al., 1999a).

Savannas exist in the sub-tropical regions of Latin America, Africa and Australia (Eamus and Prior, 2001) and in the Mediterranean climate zones, which span the Mediterranean basin of Europe and parts of California, Chile, South Africa and Australia (Joffre et al., 1999). A noted climatic feature among savannas is their exposure to prolonged wet and dry periods. This climate forcing, combined with fire and grazing, cause savanna canopies to form open, heterogeneous woodland canopies with grass understories (Scholes and Archer, 1997; Joffre et al., 1999; Higgins et al., 2000; Eamus and Prior, 2001). This heterogeneity in structure and function adds to the complexity of measuring and modeling fluxes of mass and energy over such landscapes.

The coexistence of trees and herbs in savannas has compelled many scientists to explain the relative dominance between the two plant functional types using hydrological and ecological explanations (Scholes and Archer, 1997; Higgins et al., 2000; van Wijk and Rodriguez-Iturbe, 2002). It has been theorized that trees and grasses are able to co-exist in savannas by occupying different niches, which can be separate in space or time (Eagleson, 1982; Rodriguez-Iturbe et al., 1999b), or by maintaining balanced competition with each other through disturbance-life history interactions (Scholes and Archer, 1997; Higgins et al., 2000).

The niche separation theory is derived from the observation that grasses and trees tap different soil moisture reserves and they adopt different life strategies. Grasses, for example, have a relatively shallow root system (Jackson, 1996), so they are unable to tap deep sources of water in the soil profile. To survive across the hot dry summer in Mediterranean climates, many grass species adopt an annual life cycle and transmit their genetic information in the form of seed. Trees, growing adjacent to (or over) grasses, tap deeper sources of soil water (Lewis and Burgy, 1964; Griffin, 1973; Ehleringer and Dawson, 1992; Sternberg et al., 1996) or they can remedy soil moisture deficits through hydraulic lift (Ishikawa and Bledsoe, 2000). They also have the physiological capacity to withstand severe soil water deficits (Griffin, 1988). For instance, they can decrease their hydraulic conductivity by reducing leaf area, root density and sapwood area (Eamus and Prior, 2001) or they can endure extended drought periods through stomatal closure (Xu and Baldocchi, 2003) and osmotic adjustment (Thomas et al., 1999).

To understand and critique the hydrological and ecological hypotheses that are being used to explain the presence and function of vegetation in savannas, we must characterize the water and energy balances between these ecosystems and the atmosphere on seasonal and annual time scales. So far, most of our current knowledge on water and energy exchange of savannas comes from campaign studies over relatively sparse woodlands and $\mathrm{C}_{4}$ grasses in Australia (Eamus et al., 2001; Silberstein et al., 2001), Portugal, Spain, France (Joffre and Rambal, 1993; Joffre et al., 1999), the Sahel (Huntingford et al., 1995; Kabat et al., 1997; Lloyd, 1997; Tuzet et al., 1997) and open semi-arid woodlands in Arizona (Chehbouni, 2000a; Scott et al., 2003). And, the majority of extant grassland studies reported in the literature have been confined to studies performed in the central Great 
Plains of North America, which consists of a mixture of perennial $\mathrm{C}_{4} / \mathrm{C}_{3}$ species and a climate that experiences summer rains. Published studies of note include those from the FIFE study site in Kansas (Verma et al., 1989; Kim and Verma, 1990) and Ameriflux sites in Oklahoma (Burba and Verma, 2001; Meyers, 2001), Kansas (Ham and Knapp, 1998; Bremer et al., 2001) and Canada (Wever et al., 2002). Only Valentini et al. (1995) has published measurements of carbon and water use from an annual $\mathrm{C}_{3}$ grassland in a Mediterranean climate. That study, however, did not measure the net carbon and water balance of the canopy on a continuous basis. Furthermore, it was specific to grass growing on serpentine soil near the Pacific coast, whose lower productivity is lower than other annual grasslands in California (McNaughton, 1968).

New and long-term energy balance studies on savanna and annual grasslands are needed to improve our understanding of the biophysical functioning of these systems. Such studies are also needed to provide validation data for biophysical models that are being used to assess weather and climate (Sellers, 1997; Pyles et al., 2003) and for testing new eco-hydrology theories that are being produced to predict soil water balances (Laio et al., 2001), equilibrium states vegetation and soil moisture (Eagleson, 1982; Rodriguez-Iturbe et al., 1999b) and the stability and instability of the climates of wet and dry landscapes (Brubaker and Entekhabi, 1996; Zeng and Neelin, 2000; Porporato et al., 2001).

Here we report on a comparative study of water and energy fluxes over an oak-grass savanna and an annual grassland; information on carbon dioxide exchange measurements over the grassland is discussed in a companion report (Xu and Baldocchi, 2004). These two ecosystems are located in northern California and coexist in the same climate. They contrast one another by existing on soils with different hydraulic properties and by having different geometric (canopy structure, rooting depth), physical (albedo), and physiological (phenology, stomatal control) attributes that affect energy and water fluxes.

The main objectives of this paper include:

1. Comparing radiative, convective and latent energy flux densities of an oak savanna and nearby annual grassland over the course of two growing seasons.
2. Quantifying the roles of soil water content and soil physical properties on evaporation rates and canopy conductance.

3. Quantifying the effects of canopy structure and phenology on the partitioning of energy exchange associated with understory and overstory vegetation.

Scientific questions that will be addressed in this paper include: is there a physical limit on annual evaporation of the ecosystem imposed by annual rainfall, the plant functionally type and water holding capacity of the soil? How well do the stomata regulate the loss of water by the trees? Is sensible heat exchange, during the summer, greater over a senesced grassland or a transpiring, but open woodland? Is the root system of the trees constrained by an underlying fractured rock layer or can roots penetrate through cracks and exploit moisture below the soil profile?

\section{Materials and methods}

\subsection{Site information}

Water vapor and energy exchange measurements were conducted at two field sites, which are located on the lower foothills of the Sierra Nevada Mountains, near Ione, CA (USGS 7.5' Quadrangle map: Irish Hill). One study site is classified as an oak savanna woodland (latitude: $38.4311^{\circ} \mathrm{N}$; longitude: $120.966^{\circ} \mathrm{W}$; altitude: $177 \mathrm{~m}$ ). The second site is less than $2 \mathrm{~km}$ way and is classified as a California, annual grassland (latitude: $38.4133^{\circ} \mathrm{N}$; longitude: $120.9508^{\circ} \mathrm{W}$; altitude: $129 \mathrm{~m}$ ).

\subsubsection{Climate}

Mean annual air temperature of the region is $16.6^{\circ} \mathrm{C}$, as deduced from the DAYMET climate interpolation program (http://www.daymet.org/). The mean annual precipitation is about $559 \mathrm{~mm}$ per year (this value was derived from a discontinued NCDC cooperative weather station in Ione, CA that operated between 1959 and 1977). Due to the Mediterranean climate of the region, rainfall is concentrated between October and May; essentially no rain occurs during the summer months. 


\subsubsection{Vegetation structure and dynamics}

The annual grassland is physiologically functional during the late autumn, winter and early spring and dead during the summer (Heady, 1988). When physiologically active, it contains multiple species and functional groups (grasses, forbs and nitrogen fixers) (McNaughton, 1968; Heady, 1988) and forms a closed canopy. Furthermore, water use by the grassland is in phase with the period of precipitation, but out of phase with the atmosphere's demand for water during the hot dry summer. In contrast, the oak-grass savanna possesses two distinct layers (a tree overstory and grass understory) that operate in and out of phase with each other over the course of a year (Griffin, 1988). The oak woodland is deciduous and dormant during the winter rainy period that replenishes its soil moisture reservoir. The trees leaf out in the spring and rapidly reach full photosynthetic potential (Xu and Baldocchi, 2003). After the rains cease, the trees gradually draw down the supply of moisture in the soil as they transpire. During the hot dry and rainless summer, their stomata carefully regulate water loss to avoid lethal cavitation (Griffin, 1973; Kiang, 2002; $\mathrm{Xu}$ and Baldocchi, 2003). Finally, the trees lose their leaves in the late autumn after the first big rainstorm.

The overstory of the oak savanna consists of scattered blue oak trees (Quercus douglasii). The blue oak ecosystem rings the Great Central Valley of California and inhabits the lower reaches of the Sierra Nevada foothills (Griffin, 1988; Thompson et al., 1999). Their elevational range is between 100 and $1200 \mathrm{~m}$ and their areal extent is about 2.2 million ha (Barbour and Minnich, 2000).

Blue oak trees possess a ring-porous xylem anatomy and are among the most xerophytic of associated oak species, as noted by their ability to achieve pre-dawn water potentials below $-4.0 \mathrm{MPa}$ (Griffin, 1973; Johannes et al., 1994; Ishikawa and Bledsoe, 2000; Kiang, 2002; Xu and Baldocchi, 2003).

A demographic survey on stand structure was conducted on a 100 by $100 \mathrm{~m}$ patch of forest and along a $200 \mathrm{~m}$ transect (Kiang, 2002). The mean height of the forest stand is $7.1 \mathrm{~m}$, its mode is $8.6 \mathrm{~m}$ and the maximum height is $13.0 \mathrm{~m}$. The landscape consists of approximately 194 stems per hectare, their mean diameter at breast height (dbh) is $0.199 \mathrm{~m}$ and the basal area is $18 \mathrm{~m}^{2} \mathrm{ha}^{-1}$. Also registered in the site survey, were occasional grey pine trees (Pinus sabiniana) (3 per ha).
The landscape has been managed, as the local ranchers have removed brush and cattle graze the grasses and herbs. A demographic survey detected that over $50 \%$ of the grasses and herbs in the understory of the oak savanna were represented by Brachypodium distachyon, Hypochaeris glabra, Bromus madritensis, and Cynosurus echinatus. Avena, Bromus, Erodium, Trifolium and Erodium were among the genera of herbs and grasses dominating the annual grassland site.

Leaf area index of the herbaceous vegetation was measured periodically on the using destructive sampling methods by running samples of leaves through an area meter (LICOR 3100, Lincoln, NE). Seasonal trends in leaf area index are presented in Fig. 1. Grass started growing after the commencement of autumnal rains (after day 300) and started to senesce shortly after the rains stopped in spring ( $\sim$ day 100$)$. The maximum leaf area of the grassland occurred near day 80 and reached a value near $2 \mathrm{~m}^{2} \mathrm{~m}^{-2}$. In contrast, the herbaceous vegetation in the understory of the savanna was sparser; its maximal leaf area index only approached one. Greater production of grass on the treeless landscape, than under trees of the nearby oak woodland, agrees with measurements from across the blue oak biome of northern California, where rainfall exceeds $500 \mathrm{~mm}$ per year (McClaran and Bartolome, 1989).

The oak trees covered $40 \%$ of the landscape within a kilometer of the tower (Fig. 2). Leaf area index of the oak woodland was evaluated indirectly using a plant canopy analyzer (LICOR 2000, Lincoln, NE) along a $200 \mathrm{~m}$ transect at dusk (Kiang, 2002). The open nature of the woodland (Fig. 2) resulted in a leaf area index less than one (0.65); this value was not subject to clumping corrections due to its low value. Furthermore, these results were confirmed with independent

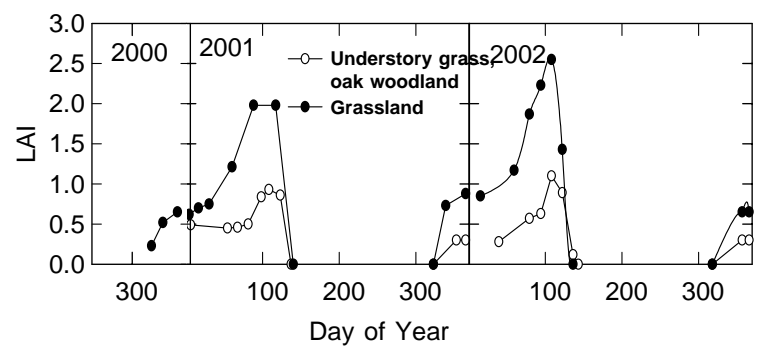

Fig. 1. Seasonal variation of leaf area index (LAI) of the annual grassland and the grass layer under the oak woodland. 
(a)

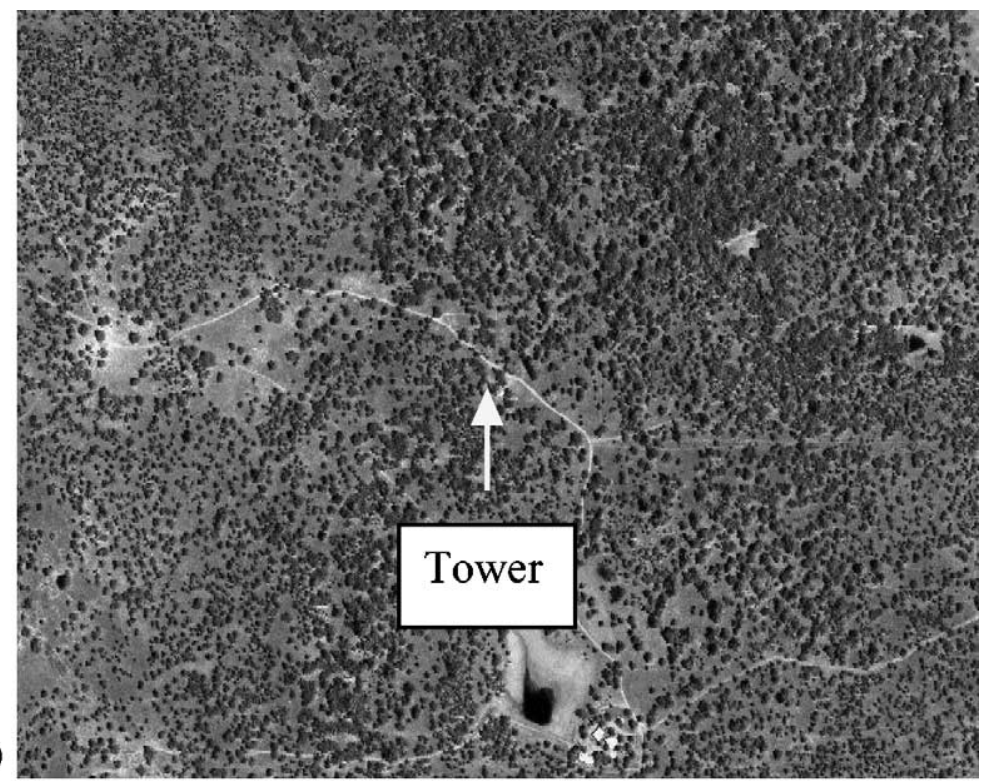

(b)

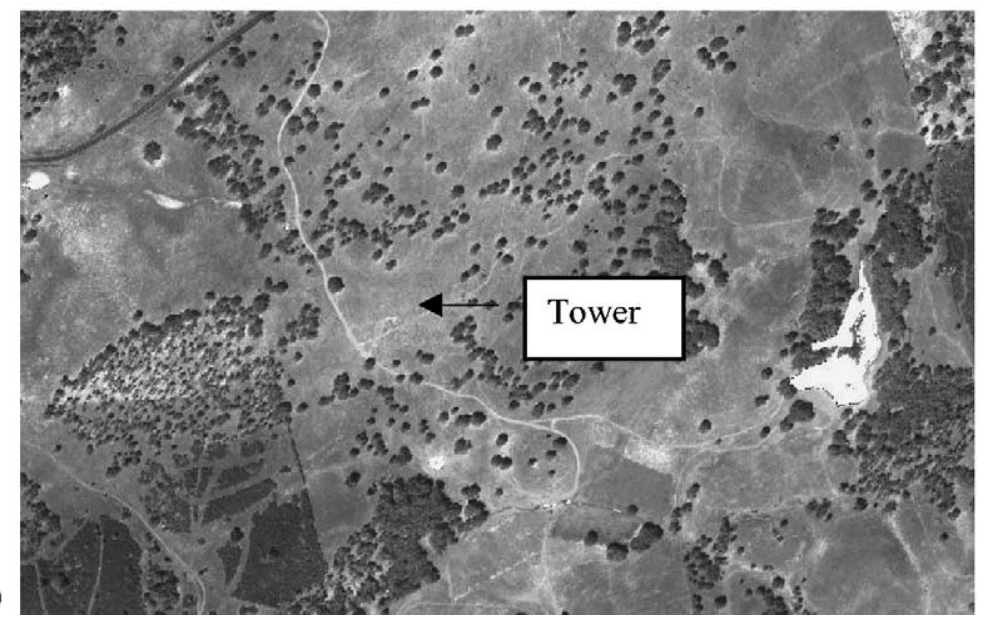

Fig. 2. IKONOS panchromatic images of the oak savanna field site (a) and the grassland (b). The spatial scale of the figures are about $1 \mathrm{~km}$ across. Pixel resolution of figure is $1 \mathrm{~m}$. Dots indicate individual tree crowns.

litterfall measurements and computations using allometric scaling algorithms (Kiang, 2002).

From a micrometeorological perspective, the field sites are nearly ideal. They are on are relatively flat terrain and possess adequate fetch. A uniform fetch of tree-grass savanna extends upwind for about $2 \mathrm{~km}$ around a central meteorological tower (Fig. 2a). The fetch of the grassland extends about $200 \mathrm{~m}$ beyond the instrument tower (Fig. 2b). Numerical footprint calculations, performed with a Lagrangian footprint model (Baldocchi, 1997) indicate that this distance was well within the flux footprint during near neutral and unstable thermal stratification.

\subsubsection{Soils}

The ecosystems are on soils classified as the Auburn-Exchequer association (Soil Survey of Amador Area, California, 1965, USDA, Soil Conservation 
Table 1

Soil physical properties, bulk density and soil texture

\begin{tabular}{lllll}
\hline & $\begin{array}{l}\text { Bulk density } \\
\left(\mathrm{g} \mathrm{cm}^{-3}\right)\end{array}$ & $\begin{array}{l}\text { Sand } \\
(\%)\end{array}$ & $\begin{array}{l}\text { Silt } \\
(\%)\end{array}$ & $\begin{array}{l}\text { Clay } \\
(\%)\end{array}$ \\
\hline Oak woodland & & & & \\
$\quad$ Under canopy & $1.58 \pm 0.136$ & 37.5 & 45 & 17.5 \\
$\begin{array}{l}\text { Open space } \\
\text { Grassland }\end{array}$ & $1.64 \pm 0.107$ & 48 & 42 & 10 \\
\hline
\end{tabular}

Service). Specifically, the soil of the grassland site is an Exchequer very rocky silt loam (Lithic xerorthents). The soil of the oak-grass savanna is an Auburn very rocky silt loam (Lithic haploxerepts). Ground penetrating radar measurements reveal that the soil layer was about $1.0 \mathrm{~m}$ thick and that it overlaid fractured greenstone bedrock (Susan Hubbard, Lawrence Berkeley National Lab, personal communication). Physical properties (bulk density, texture) of the soils are presented in Table 1. Soil texture was analyzed at Division of Agriculture and Natural Resources (DANR) Analytical Soils Laboratory, University of California-Davis.

Soil water retention curves were quantified using a dewpoint hygrometer (model WP4, Decagon Devices, Inc., Pullman, WA). Parameters for the mathematical representation of the water retention curve, using a power law model, are listed in Table 2.

\subsection{Meteorological and soil measurements}

Environmental measurements started early November 2000 at the grassland site and late April 2001 at the oak woodland; measurements continue as we write this paper. Radiation flux densities were measured above the canopies with an upward and downward facing quantum sensor (PAR Lite, Kipp and Zonen, Delft, Netherlands), a pyranometer (CM 11, Kipp and Zonen, Delft, Netherlands), and a net radiometer (NR Lite, Kipp and Zonen, Delft, Netherlands),

Table 2

Parameters for water retention curve between volumetric water content $\left(\theta_{\mathrm{v}}\right)\left(\mathrm{cm}^{3} \mathrm{~cm}^{-3}\right)$ and soil water potential, $\psi(\mathrm{MPa})=a \theta_{\mathrm{v}}^{\mathrm{b}}$

\begin{tabular}{llll}
\hline Site & Soil & $a$ & $b$ \\
\hline Oak savanna & Auburn & -0.0043 & -2.569 \\
Grassland & Exchequer & -0.0178 & -2.013 \\
\hline
\end{tabular}

respectively. Air temperature and relative humidity were measured with a platinum resistance thermometer and solid-state humicap, respectively (model HMP-45A, Vaisala, Helsinki, Finland). These sensors were shielded from the sun and aspirated. Static pressure was measured with capacitance barometers (model PTB101B, Vaisala, Helsinki, Finland). Rainfall was measured with a tipping bucket rain gauge (Texas Electronics, TE $5252 \mathrm{~mm}$ ).

Soil moisture was measured with three methods that vary in their spatial and temporal attributes. Volumetric soil moisture content was measured continuously with an array of frequency domain reflectometry sensors (Theta Probe model ML2-X, Delta-T Devices, Cambridge, UK). The probes sense $60 \mathrm{~mm}$ segments of soil and deduce soil moisture by measuring the dielectric constant in the contained soil matrix. Sensors were placed at various depths in the soil (surface, 10, 20 and $50 \mathrm{~cm}$ ) and were calibrated using the gravimetric measurements of soil moisture. Profiles of soil moisture were obtained across a wider spatial domain on a periodic basis ( $\sim$ weekly) using segmented, time-domain, reflectometer probes (Moisture Point, model 917, Environmental Sensors, Inc., Victoria, British Columbia). Five segmented probes $(0-15$, $15-30,30-45$ and $45-60 \mathrm{~cm}$ ) were installed at the woodland and two segmented probes were installed at the grassland. Pre-dawn leaf water potential was measured periodically to assess the integrated soil water potential sensed by the root system. A plant water status pressure chamber was used for this measurement (Model 3000, Soil Moisture Equipment Corp., Goleta, CA). Typically twenty leaves from 10 trees were sampled.

Because the roots vary with depth and extract water from the soil profile in a non-uniform way, we computed a representative metric of available soil moisture by weighting soil moisture by the probability distribution of roots by depth:

$\langle\theta\rangle=\frac{\int_{Z}^{0} \theta(z)(\mathrm{d} p(z) / \mathrm{d} z) \mathrm{d} z}{\int_{Z}^{0}(\mathrm{~d} p(z) / \mathrm{d} z) \mathrm{d} z}$

The probability density of roots by depth, $\mathrm{d} p / \mathrm{d} z$, in Eq. (1) was derived from the cumulative probability distribution of roots, $p$, from representative ecosystems (Jackson, 1996), where $p(z)=1-\beta^{z}$, $z$ is depth in centimeters, and $\int_{Z}^{0}(\mathrm{~d} p(z) / \mathrm{d} z) \mathrm{d} z$ sums to one. 
Drawing on data from Jackson (1996), we assigned $\beta$ to be 0.94 for the grassland. For the oak woodland, we deduced $\beta$ using data from Ishikawa and Bledsoe (2000). They reported that $70 \%$ of excavated root biomass of a blue oak woodland is located, on average, above $0.5 \mathrm{~m}$, which produces a $\beta$ value of 0.976 .

Soil temperatures were measured with multi-level thermocouple probes. The sensors were spaced logarithmically at $0.02,0.04,0.08,0.16$ and $0.32 \mathrm{~m}$ below the surface. Four probes were placed in the soil at the woodland and two were used to sample soil temperature at the grassland. Soil heat flux density was measured by averaging the output of three soil heat flux plates (model HFP-01, Hukseflux Thermal Sensors, Delft, The Netherlands) at each site. They were buried $0.01 \mathrm{~m}$ below the surface and were randomly placed within a few meters of the flux system. The gradual build up of plant matter changed the thermal properties of the upper layer. Consequently, heat storage was quantified in the upper layer by measuring the time rate of change in temperature using the method of Fuchs and Tanner (1967).

Canopy heat storage of the woodland was calculated by measuring the time rate of change in bole temperature. Bole temperatures were measured in ten trees using three thermocouples per tree. Those sensors were placed about one $\mathrm{cm}$ into the bole and were azimuthally space across a tree at breast height. Using information on tree density and diameter at breast height, the storage measurements of heat flux were scaled to the landscape. For periods with missing tree temperature we estimated canopy heat storage using a second order polynomial that regressed canopy heat storage $(S)$ on net radiation $\left(R_{\mathrm{n}}\right) ; r^{2}=0.82, b_{0}=$ $13.6 ; b_{1}=-0.192 ; b_{2}=0.000185$.

Ancillary meteorological and soil physics data were acquired and logged on Campbell CR-23x and CR-10x data loggers. The sensors were sampled every few seconds and half-hour averages were computed and stored on a computer, to coincide with the flux measurements.

\subsection{Eddy covariance instrumentation and flux density calculations}

The eddy covariance method was used to measure water, heat and $\mathrm{CO}_{2}$ flux densities between the biosphere and atmosphere (Baldocchi, 2003). Positive flux densities represent mass and energy transfer into the atmosphere and away from the surface and negative values denote the reverse.

Wind velocity and virtual temperature fluctuations were measured with a three-dimensional ultra-sonic anemometer (Windmaster Pro, Gill Instruments, Lymington, UK). Carbon dioxide and water vapor fluctuations were measured with an open-path, infrared absorption gas analyzer (model LI-7500, LICOR, Lincoln, NE). The micrometeorological sensors were sampled and digitized 10 times per second.

At the savanna site, a set of micrometeorological instruments was supported $23 \mathrm{~m}$ above the ground ( $\sim 10 \mathrm{~m}$ over the forest) on a walk-up scaffold tower. The gas analyzer was mounted $0.35 \mathrm{~m}$ below the sonic and $0.25 \mathrm{~m}$ to the side of the anemometer. Another set of flux measurement instrumentation was mounted about $2 \mathrm{~m}$ above the ground in the understory. And a set of flux measurement instrumentation was mounted on a tripod tower $2 \mathrm{~m}$ above the ground at the grassland. Each tower was protected from the cows with an electrical fence.

In-house software was used to process the measurements into flux densities. The software computed covariances between velocity and scalar fluctuations over half-hour intervals. Turbulent fluctuations were calculated using the Reynolds decomposition technique by taking the difference between instantaneous and mean quantities. Mean velocity and scalar values were determined using $30 \mathrm{~min}$ records. The computer program also removes electrical spikes and rotates the coordinate system to force the mean vertical velocity to zero. Corrections for the effect of density fluctuations were applied to the scalar covariances that were measured with the open-path sensor using theory developed by Webb et al. (1980). Recent papers (Paw et al., 2000; Finnigan et al., 2003) have recommended using the planar rotation method of instead of classic coordinate rotation method to compute flux covariances. Test calculations revealed that the classic coordinate rotation method produced similar results as the planar rotation method; this occurred in part because the mean angle of rotation for the grassland and woodland was less than $1.3^{\circ}$.

The fast response $\mathrm{CO}_{2}$ /water vapor sensors were calibrated every 3-4 weeks against gas standards. The calibration standards for $\mathrm{CO}_{2}$ were traceable to those prepared by NOAA's Climate Monitoring and 
Diagnostic Laboratory. The output of the water vapor channel was referenced to a dew point hygrometer (LI-610, Licor, Lincoln, NE). Over the past two years the calibration zeros and spans have shown negligible drift.

\subsection{Data quality and assurance}

Prior to the experimental set up computations of the flux covariance transfer functions (Moore, 1986) were made to guide the positioning of sensors in the field. Overall transfer correction factors were less than a few percent. Considering uncertainties with applying the transfer functions, we chose not to apply them to our data.

One measure of testing data quality is to test for closure of the surface energy balance (Wilson, 2002). Using data from 2001, we report that the slope between net radiation flux density $\left(R_{\mathrm{n}}\right)$ and the sum of sensible $(H)$, latent heat $(\lambda E)$ and soil heat flux $(G)$ densities for the grassland study was 0.92 , the intercept was $1.13 \mathrm{~W} \mathrm{~m}^{-2}$, and the coefficient of determination $\left(r^{2}\right)$ was 0.974 . For the savanna system, the linear regression between $R_{\mathrm{n}}$ and the sum of $\lambda E, H, G$ and canopy heat storage $(S)$ produced an intercept of 0.69 , a slope of 0.87 and a coefficient of determination $\left(r^{2}\right)$ of 0.93 . While our ability to close the surface energy balance is imperfect it ranks among the sites with the highest degree of energy balance closure, according to a synthesis by Wilson (2002) using data from the FLUXNET network.

Many factors can account for imperfect, but satisfactory, degree of energy balance closure. For this study we cite that the net radiation, $S$ and $G$ measurements at the woodland site were not representative of the flux footprint associated with $\lambda E$ and $H$. The net radiometer was mounted on a tall tower. Because it extended only one meter from the tower it saw a mix of open canopy, tower and trees. In addition, the number of available datalogger channels and wire length limited the spatial sampling of $G$ and $S$. If we examine energy balance closure of the savanna on a $24 \mathrm{~h}$ basis, which tends to force error prone storage terms $(G$ and $S$ ) to sum to near zero, an improvement in energy balance closure was attained for this field site (Fig. 3), giving us better confidence on the daily and seasonal sums of energy exchange that are presented in this paper.

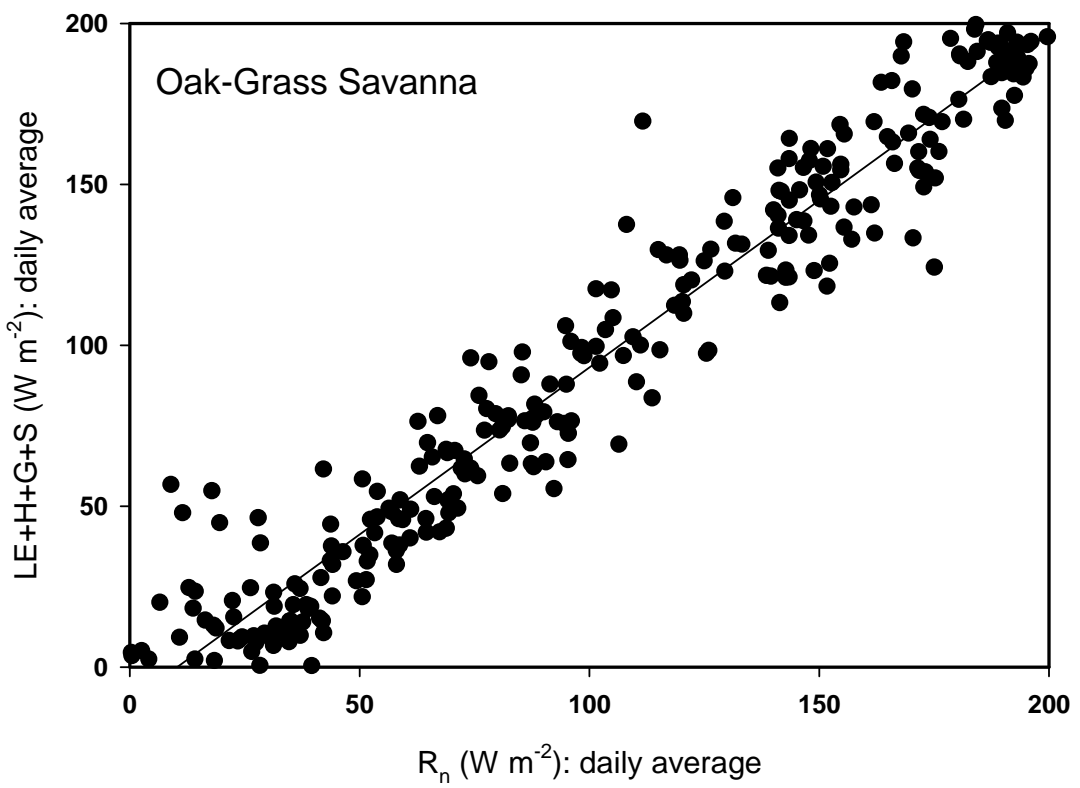

Fig. 3. Test of energy balance closure. Daily average fluxes of net radiation $\left(R_{\mathrm{n}}\right)$ are compared against the sums of sensible $(H)$, latent $(\lambda E)$, and soil heat flux $(G)$ and canopy heat storage $(S)$. The linear regressions produced an intercept of $-10.6 \mathrm{~W} \mathrm{~m}{ }^{-2}$, a slope of 1.036 and an $r^{2}$ of 0.94 . 
Data gaps are inevitable and must be filled to compute daily and annual sums of fluxes. We filled data gaps with the mean diurnal average method (Falge, 2001). The diurnal means were computed for consecutive 26-day windows to account for seasonal trends in phenology and soil moisture. The 26-day window corresponds well with a spectral gap in energy fluxes (not shown), suggesting that this time window was nearly optimal.

\section{Results and discussion}

\subsection{Weather and climate}

To understand how plant functional-type, weather, seasonal drought, and soil physical properties alter energy balance partitioning of an oak-grass savanna and a nearby grassland, we first present background information on some key environmental variables (solar and net radiation, air temperature and soil moisture). Solar radiation is the main energy source of the ecosystem and microclimate. Data on the seasonal pattern of daily-integrated global solar radiation $\left(R_{\mathrm{g}}\right)$ and net radiation $\left(R_{\text {net }}\right)$ are presented in Fig. 4. Between the winter and summer solstices, peak values of daily-integrated solar radiation gradually increased from about 10 to $30 \mathrm{MJ} \mathrm{m}^{-2}$ per day. During the winter, spring and autumn, rain and fog caused values of daily solar radiation to drop below the upper envelope. Conversely, most days were clear during the summer, and daily sums tended to fall along the upper envelope of the seasonal trend. On an annual basis the field sites received about $6.7 \mathrm{GJ} \mathrm{m}^{-2}$ per year of solar energy. This value is among the highest values observed at sites across North and South America (Ohmura and Gilgen, 1993) and is consistent with historical measurements at two climate stations in sunny northern California (Major, 1988). On a global basis, these data are exceeded only by radiation measurements in the semi-arid and desert regions of South Africa, central Australia, the Middle East and portions the Indian subcontinent (Ohmura and Gilgen, 1993).

The net radiation balances of the two contrasting field sites differed markedly (Fig. 4) despite receiving identical sums of solar radiation and longwave radiation. During 2002, the daily integral of the net radiation flux density was greater over the woodland,

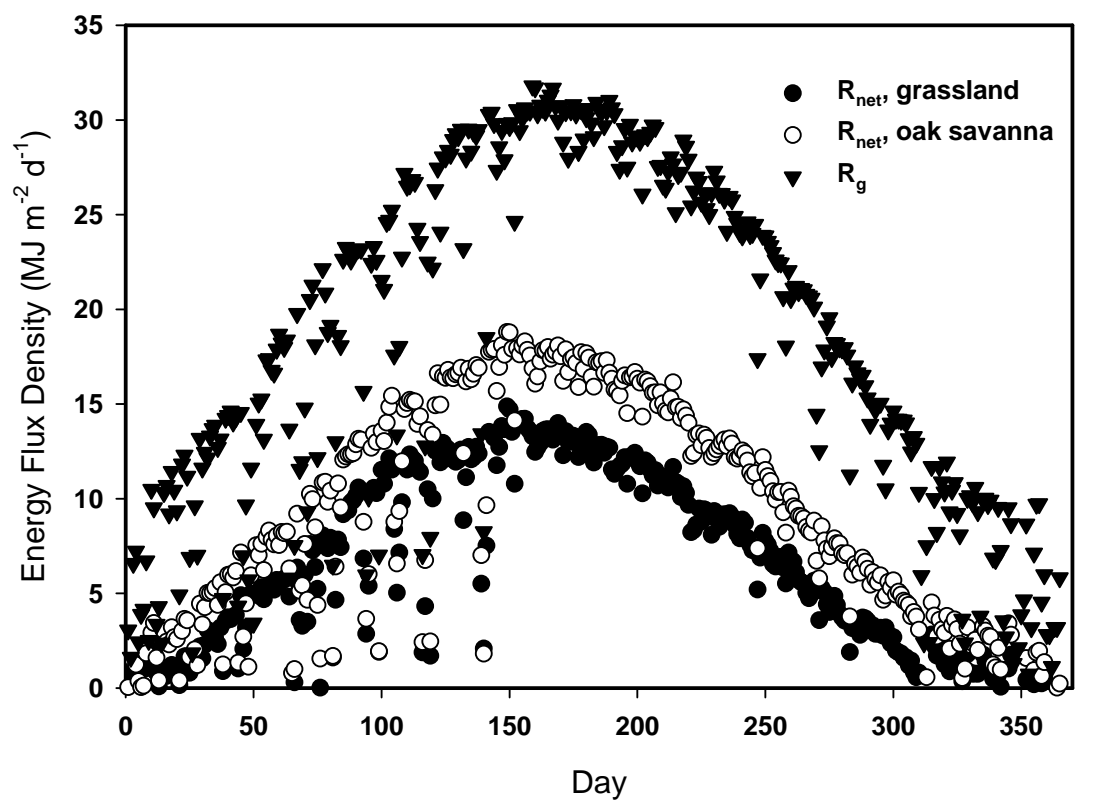

Fig. 4. Seasonal variations in global solar radiation, $R_{\mathrm{g}}$, and net radiation, $R_{\mathrm{n}}$. Each datum represents hourly measurements integrated over the course of a day. Net radiation data are presented for measurements over the annual grassland and over the oak savanna. These data are for the year 2002 . 


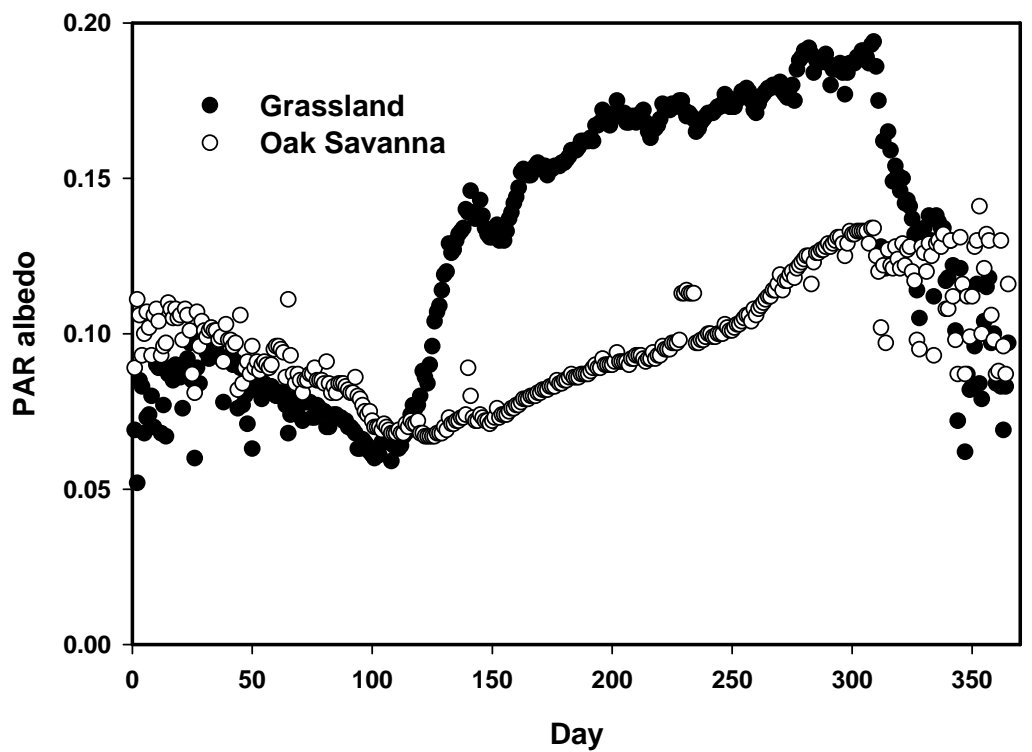

Fig. 5. Seasonal variation in daily-averaged albedo of photosynthetically active radiation (PAR). Data are from 2002 and are weighted by solar radiation.

throughout the year. On an annual basis, $3.25 \mathrm{GJ} \mathrm{m}^{-2}$ of net radiation was available to the woodland during 2002 while grassland net radiation budget ranged between 2.1 and $2.3 \mathrm{GJ} \mathrm{m}^{-2}$ during 2001 and 2002.

Seasonal trends in the albedo of visible sunlight are shown in Fig. 5. Starting in January, albedo of the grassland and woodland decreased as the grass canopy greened and grew, gradually obscuring bare soil and detritus. Comparatively, albedo of the dormant and bare woodland was slightly greater than the open grassland during this period as the bare trees were more reflective. A switch in temporal trend of albedo occurred around day 100, which coincided with the period of minimum albedo, for both the woodland and grassland. The switch was prompted by the reproductive heading of the grasses and was reinforced by their sequential senescence (Xu and Baldocchi, 2004). And during the summer the dead grass was 'golden' and highly reflective.

The temporal switch in albedo was less abrupt over the woodland, as the period near day 100 also coincided with the expansion of leaves. During the summer the woodland had a lower albedo than the grassland because the multi-storied structure of the woodland trapped sunlight, even though the grass understory was dead and highly reflective. Differences in PAR albedo during the summer partially explain the observed differences in $R_{\mathrm{n}}$ (Fig. 4).

Differences in emitted longwave radiation may provide another part of the explanation to the question: 'why there was a difference in the net radiation balance of the two sites?' We did not have radiative temperature measurements at both sites, but we were able to compute aerodynamic temperatures $\left(T_{\text {aero }}\right)$, from measurements of sensible heat flux density, the aerodynamic resistance to heat transfer and air temperature, and use them as a proxy for surface temperature. Over the course of the year 2002, the mean aerodynamic temperatures of the two canopies were very similar ( $T_{\text {aero }}$ for the oak woodland was $17.95 \pm 0.43^{\circ} \mathrm{C}$ and $T_{\text {aero }}$ for the grassland was $17.58 \pm 0.74^{\circ} \mathrm{C}$ ). While the mean aerodynamic temperature of the oak woodland was significantly greater than that of the grassland $(t=3.337 ; P=0.0009)$, the observed temperature differences cannot account for the differences in $R_{\text {net }}$ through longwave energy losses, as these temperature difference represent a $2 \mathrm{~W} \mathrm{~m}^{-2}$ potential difference in longwave energy emission.

The seasonal trends in maximum and minimum temperature are shown in Fig. 6. Maximum and minimum air temperatures are rather mild during the winter. Maximum temperatures during the grass's growing 


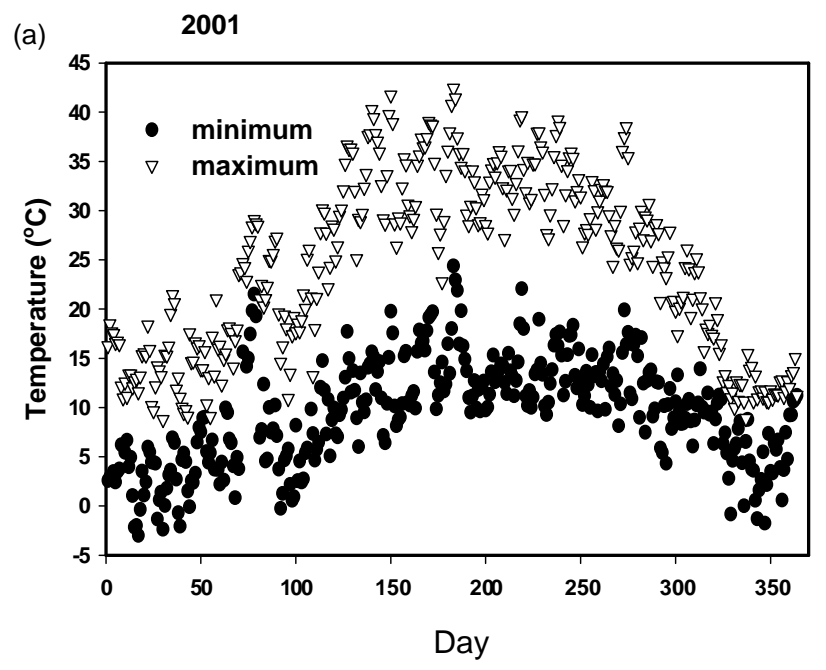

(b) 2002

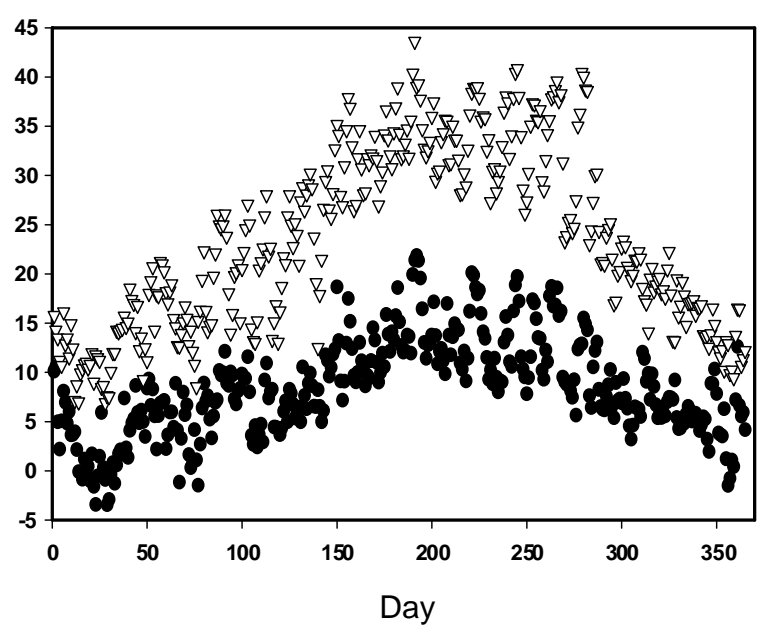

Fig. 6. Seasonal trend in maximum and minimum air temperature measured over a California annual grassland near Ione, CA. Part (a) is from 2001 and part (b) is from 2002.

season, the winter and spring, were rarely above $15^{\circ} \mathrm{C}$ and minimum temperatures never dropped below $-5^{\circ} \mathrm{C}$. But frost and freezing were frequent during the winter and their occurrence stymied growth of the grass and stomatal opening (Xu and Baldocchi, 2004). During the summer, after the grass died, maximum air temperature often exceeded $40^{\circ} \mathrm{C}$ in the afternoon and dropped below $10^{\circ} \mathrm{C}$ at night. The passage of weather fronts and changes in air masses caused much variation in maximum and minimum temperatures $\left(10-15^{\circ} \mathrm{C}\right)$ on a weekly basis, throughout the year.

Seasonal trends of soil moisture are presented in Fig. 7. The maximum soil moisture content, integrated across the upper $0.60 \mathrm{~m}$ of the soil profile, occurred during the winter rainy season. But the maximum amount of water each soil held differed. After repeated winter rainstorms, the maximum soil moisture values were $0.31 \mathrm{~m}^{3} \mathrm{~m}^{-3}$ and 0.44 at the grassland and oak savanna sites, respectively. The maximum moisture content at the savanna corresponded well with the computation of field capacity from the soil-water release curve (the volumetric water content at $-0.033 \mathrm{MPa}$ is $0.45 \mathrm{~m}^{3} \mathrm{~m}^{-3}$ ). The maximum soil moisture at the grassland, on the other hand, did not match the theoretical estimate of field capacity well, and instead corresponded with a wa- ter potential of $-0.19 \mathrm{MPa}$. The grassland site may experience more drainage and lateral flow than the woodland because of its slightly convex topography. After the rains stopped in the spring, vegetation at both sites progressively depleted moisture from the soil profile. By the start of the autumnal rains (after day 300) the minimum soil moisture at both sites had dropped to about $0.09 \mathrm{~m}^{3} \mathrm{~m}^{-3}$ (a soil water potential corresponding to about $-3.0 \mathrm{MPa})$.

The differences we see in soil texture, bulk density and water holding capacity at the two sites are consistent with other reports on savannas. Joffre and Rambal (1988), for example, show that bulk density and moisture retention differed between tree-covered area and open area and soil water content was higher in tree covered areas. And Jackson et al. (1990) report better soil hydraulic properties under trees in California oak woodlands.

\subsection{Evaporation and sensible heat exchange: temporal dynamics}

With information on canopy structure and climate on hand we next address how these factors affect the magnitudes and temporal dynamics of evaporation $(E)$ and sensible heat $(H)$ exchange of the savanna and grassland systems. 


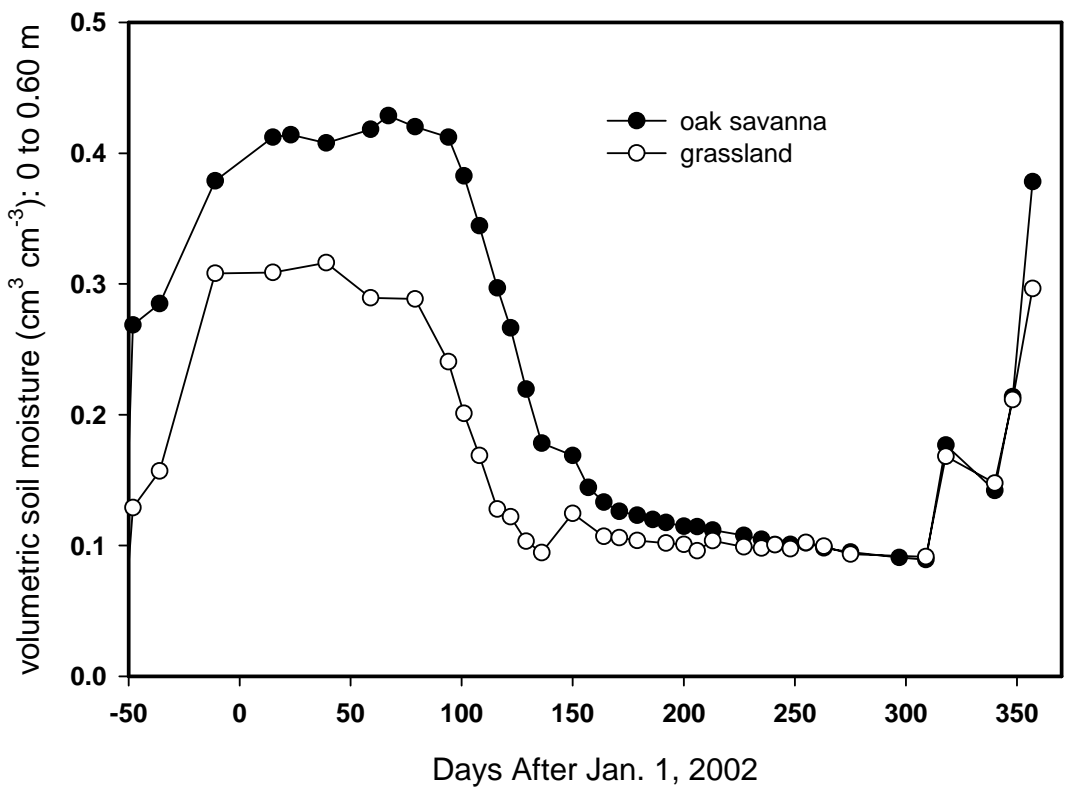

Fig. 7. Seasonal trend of volumetric soil moisture at the grassland and oak woodland sites. The measurements were weighted by the vertical distribution of roots. A spatial array of segmented, time domain reflectometer probes were used to measure soil moisture at weekly intervals.

A comparison of daily-integrated evaporation, $E$, for the oak woodland and grassland is shown in Fig. 8. During the winter periods, less than $1 \mathrm{~mm}$ per day evaporated from the two contrasting sites. With the approach of spring, evaporation rates at both sites increased day-by-day until peak rates of $4 \mathrm{~mm}$ per day were achieved. Temporal increases in demand (net radiation) and supply (leaf area index of the grassland and savanna understory) were responsible for this trend (Figs. 1 and 4). Close inspection of Fig. 8 shows that slightly greater rates of evaporation occurred from the grassland, during spring, which we attribute to differences in leaf area index; the leaf area index of the grassland was greater than that of the grass under the dormant and leafless oak woodland. By late spring and summer the situation switched. Then evaporation from the woodland greatly exceeded that from the grassland, which had died and was not transpiring. And by late summer both landscapes were evaporating at very low levels, below $0.3 \mathrm{~mm}$ per day, as low soil water potentials promoted stomatal closure (Kiang, 2002; Xu and Baldocchi, 2003).

Annual evaporation and water budgets are summarized in Table 3, on a calendar year basis. We calculate that much more water evaporated from the woodland over a year (381 $\mathrm{mm}$ per year) than from the nearby annual grassland $(\sim 300 \mathrm{~mm}$ per year). We also observe that annual precipitation exceeded actual evaporation at both sites; the ratio ranged between 1.29 and 1.85. Annual budgeting of rainfall, however, can be misleading and may not represent the amount of water available to the plants because surplus rainfall occurs in the winter and either runs off the surface or drains past the root system.

The evaporative water balances at our study sites are near the thresholds ( $\sim 400 \mathrm{~mm}$ per year) of supporting grass or woodland (Stephenson, 1998). Consequently,

Table 3

Annual budgets of measured evaporation $(E)$, equilibrium evaporation $\left(E_{\mathrm{eq}}\right)$, precipitation $(\mathrm{ppt})$, net radiation $\left(R_{\mathrm{n}}\right)$ and derived ratios

\begin{tabular}{lcll}
\hline & $\begin{array}{l}\text { Grassland } \\
2001\end{array}$ & $\begin{array}{l}\text { Grassland } \\
2002\end{array}$ & $\begin{array}{l}\text { Oak woodland } \\
2002\end{array}$ \\
\hline$E$ (mm per year $)$ & 299 & 290 & 381 \\
$E_{\text {eq }}($ mm per year $)$ & 568 & 601 & 864 \\
$\mathrm{ppt}(\mathrm{mm})$ & 556 & 494 & 494 \\
$R_{\mathrm{n}}\left(\mathrm{GJ} \mathrm{m}^{-2}\right.$ year $^{-1)}$ & 2.11 & 2.29 & 3.25 \\
$\mathrm{ppt} / E$ & 1.85 & 1.70 & 1.29 \\
$\mathrm{ppt} / E_{\mathrm{eq}}$ & 0.98 & 0.82 & 0.57 \\
$H\left(\mathrm{GJ} \mathrm{m}^{-2}\right.$ per year $)$ & 1.23 & 1.46 & 2.05 \\
\hline
\end{tabular}




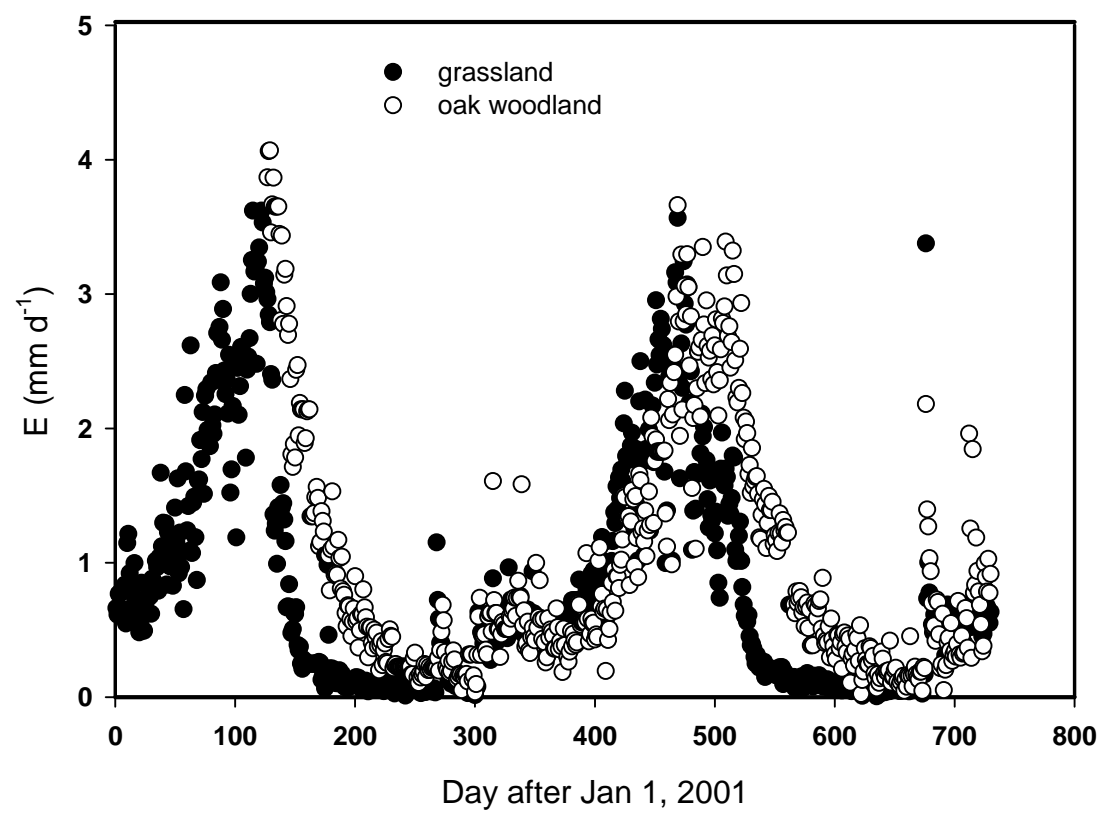

Fig. 8. Seasonal variation in daily-integrated evaporation, $E$, from an oak woodland and an annual grassland.

slight differences in soil water holding capacity may play a partial, if not critical, role as to whether trees exist or are absent at one of the sites (Joffre and Rambal, 1993). With respect to our two study sites, the upper $0.60 \mathrm{~m}$ of the soil holds $210 \mathrm{~mm}$ of water at the woodland site and the soil at the grassland site holds $132 \mathrm{~mm}$ of water. This difference of $78 \mathrm{~mm}$ corresponds very well with the difference in annual evaporation at the two field sites, which can be effectively exploited by the woodland once the rains stop. The differences we report in evaporation for the two sites is also supported with results from a Spanish dehesa, where it was observed that between 100 and $200 \mathrm{~mm}$ more water was stored in the soil under trees than in the open grassland between trees (Joffre and Rambal, 1993).

To quantify whether atmospheric demand or biospheric supply is the limiting factor on an annual time scale, we compared actual evaporation rates with estimates of potential evaporation; for convenience we defined the potential rate as the equilibrium evaporation rate $\left(E_{\mathrm{eq}}\right)$ :

$E_{\mathrm{eq}}=\frac{s}{\lambda(s+\gamma)}\left(R_{\mathrm{n}}-G-S\right)$ where $s$ is the slope of the saturation vapor pressuretemperature function and $\gamma$ is the psychrometric constant; alternatively one could use the Priestley-Taylor rate which is 1.26 times $E_{\text {eq }}$. The annual totals of evaporation from both sites were between 40 and 50\% of potential evaporation. Furthermore, potential evaporation exceeded precipitation. These results indicate that the regulation of transpiration by plant functional (stomatal regulation) and structural properties (leaf area index, plant form) and life history/phenology are required to achieve a positive water balance at both sites.

Seasonal information on the biosphere's control of evaporation is provided in Fig. 9 in the form of the canopy surface conductance, $G_{c}$; this variable was derived by evaluating an inverted form of the Penman-Monteith equation (Kelliher et al., 1995). During the rainy season, $G_{\mathrm{c}}$ was largest, but it ranged widely day-to-day $\left(0.2-0.6 \mathrm{~mol} \mathrm{~m}^{-2} \mathrm{~s}^{-1}\right)$, reflecting the evaporation from wet or dry surfaces and the alternation of cloudy and sunny days. Although $G_{\mathrm{c}}$ is a function of leaf area index and stomatal conductance, it was difficult to detect a distinct effect of changing leaf area index on $G_{\mathrm{c}}$ during the rainy season due to the large day-to-day variance. With the cessation of 


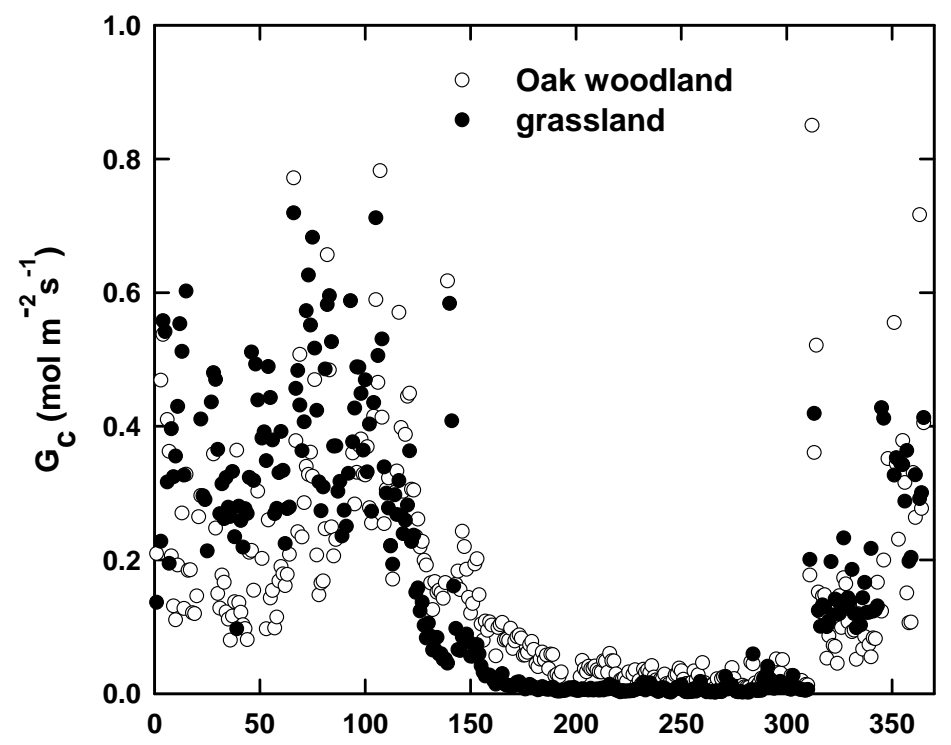

Fig. 9. Seasonal variation in canopy surface conductance, $G_{\mathrm{c}}$. Daily averages of $G_{\mathrm{c}}$ were weighted by the daily course in photosynthetically active radiation.

winter rains $G_{\mathrm{c}}$ experienced less day-by-day variance, and dropped gradually with time. At the grassland site, $G_{\mathrm{c}}$ approached zero $\left(<0.005 \mathrm{~mol} \mathrm{~m}^{-2} \mathrm{~s}^{-1}\right)$ by midsummer, reflecting the death of the grasses. In comparison to the grassland, the canopy conductance of the transpiring savanna was greater $\left(G_{\mathrm{c}} \sim\right.$ $\left.0.02 \mathrm{~mol} \mathrm{~m}^{-2} \mathrm{~s}^{-1}\right)$. However, its dry season values were about one-tenth of its winter leafless values as a result of progressive stomatal closure.

Our measurements of annual evaporation agree favorably with simple estimates of 'actual' evaporation produced by Major (1988) for oak savanna landscapes in California, using the Thornthwaite equation and a soil moisture bookkeeping method. With this simple method, Major produced evaporation values that ranged between 280 and $382 \mathrm{~mm}$ per year. The measured evaporation rates from the savanna, reported in Table 3, are also on par with data produced by Lewis et al. (2000) from a 17 year watershed study of oak woodlands at the Sierra Foothills field station; they reported that average evaporation was $368 \pm 89 \mathrm{~mm}$ at a site with $708 \pm 259 \mathrm{~mm}$ of rainfall. In contrast, a greater difference in the water balance of an open grassland and a tree-grass system was reported for the Spanish "dehesas" savanna (Joffre and Rambal, 1993);
$400 \mathrm{~mm}$ of water was lost from an open grassland and $590 \mathrm{~mm}$ of water was lost from the trees-grass system.

The sparseness of the woodland, we are studying, and its occupation in a semi-arid climate, resulted in annual evaporation sums that were below those for mixed species oak forests in the humid and temperate zone of eastern United States, which evaporate more than $500 \mathrm{~mm}$ of water per year (Moore, 1996; Wilson and Baldocchi, 2000). We also recorded sums of evaporation that were lower than transpiration values for evergreen oak savanna growing on the coastal range of California (Goulden, 1996); a landscape of Quercus agrifolia transpired $443 \mathrm{~mm}$ and $Q$. durata transpired $570 \mathrm{~mm}$ in a year. Evergreen oaks in northern California grow in a wetter and cooler climate and access ground water (Griffin, 1988) which limits the degree of stomatal closure during the summer.

The amount of annual evaporation from our grassland falls between sums reported for grasslands growing in the Canadian prairie (Wever et al., 2002) and southern Great Plains (Burba and Verma, 2001); the Canadian prairie evaporates about $250 \mathrm{~mm}$ of water per year and the grassland in the southern end evaporates over $1000 \mathrm{~mm}$ over a year. Having a winter/spring growing season, thereby, enables the 
California annual grassland to complete its life cycle on less water than if it was growing as a perennial $\mathrm{C}_{3} / \mathrm{C}_{4}$ grassland in the southern Great Plains with a summer growing season.

The lower rate of evaporation that we observed over the grassland, as compared to the oak savanna, is supported by measurements from a paired watershed study. Lewis (1968) converted an oak woodland watershed to grassland and found that consumptive water use dropped from 513 to $378 \mathrm{~mm}$ per year, a $26 \%$ decrease in evaporation. On the other hand, grazing is expected to have had only a minor effect on evaporation. Bremer et al. (2001) reported that grazing reduced seasonal evaporation for a grassland in Kansas by only $6 \%$. And light and heavy grazing had a negligible affect on $\mathrm{CO}_{2}$ exchange, and by inference evaporation, in another study (Lecain et al., 2000).

Fingerprint diagrams are a convenient way to distill the diurnal and seasonal dynamics of a large pool of sensible heat flux density, $H$, data from the grassland and woodland sites (Fig. 10). The most notable observation is that peak rates of $H$ were much greater over the transpiring oak woodland during the summer than over the dead, dry grassland. The aerodynamically rough features of the open woodland, combined with a relatively low albedo, to produce $H$ values exceeding $450 \mathrm{~W} \mathrm{~m}^{-2}$, during summer. In contrast, less energy was available to the grassland and its aerodynamically smoother canopy produced lower values of $H$, which peaked near $350 \mathrm{~W} \mathrm{~m}^{-2}$. On an annual basis, $H$ over the grassland was almost $30 \%$ less than the sensible heat exchange measured over the oak woodland.

The peak $H$ values over the oak woodland are among the top rates we have measured or seen reported in the literature for energy exchange of vegetated surfaces. Only measurements of $H$ from an arid steppe shrubland in eastern Oregon (Doran, 1992) approach $450 \mathrm{~W} \mathrm{~m}^{-2}$ and another study, over a desert with CAM species, reported $H$ values approaching $500 \mathrm{~W} \mathrm{~m}^{-2}$ (Unland et al., 1996). Other reports of large sensible heat flux densities from vegetated surfaces in dry semi-arid climates, such as a dry grassland in Arizona (Chehbouni, 2000b), a dry boreal jack pine forest in Canada (Baldocchi et al., 1997) and a dry savanna in Niger (Lloyd, 1997) were lower than values reported here; they only approached $350 \mathrm{~W} \mathrm{~m}^{-2}$.

\subsection{Processes and controls}

\subsubsection{Understory evaporation}

Since savanna form open complexes, the net water balance of the landscape is composed of a fraction of water from the tree overstory and the grasses in the understory and open spaces. Our understory eddy flux measurements enable us to quantify the fraction of water that comes from the soil/grass understory versus the overstory (Fig. 11). During the winter, between 40 and $60 \%$ of canopy evaporation came from the understory. This ratio did not equal one when the trees were leafless, as one may have expected, because up to $1 \mathrm{~mm}$ per day of water can be lost from the stems and branches of leafless trees (Kiang, 2002). After the trees leafed out, starting around day 90, the contribution of the understory to the overall evaporation diminished. And by summer less than $10 \%$ of the evaporation water came from the understory of the woodland. Over the course of the year, $139 \mathrm{~mm}$ of water evaporated from the understory, which represents $36 \%$ of the moisture that evaporated from the landscape.

The understory of this oak woodland, when the grass was green, had a greater proportional contribution to canopy evaporation than the understory of a boreal jack pine (Baldocchi et al., 1997), a boreal spruce/pine (Constantin et al., 1999), a ponderosa pine (Baldocchi et al., 2000) and a temperate deciduous forest (Wilson et al., 2000); understory evaporation of the cited works constitute between 5 and $30 \%$ of canopy evaporation. On the other hand, our values are on par with measurements from a semi-arid woodland in Arizona (Scott et al., 2003).

\subsubsection{Evaporation and soil moisture}

To quantify the relationship between evaporation and soil moisture, ecohydrological models require information on the maximum evaporation rate, the soil moisture at which evaporation begins to decline and the soil moisture content at which evaporation rates equal zero (Laio et al., 2001). Yet direct measurements of the response of canopy evaporation to changes in soil moisture are rare (Kelliher et al., 1993; Hunt et al., 2002) or exist across a limited range of soil moisture conditions due to intermittent rainfall (Baldocchi et al., 1997). Furthermore, the functional shape for the response of tree transpiration to soil moisture deficits shows much more diversity 

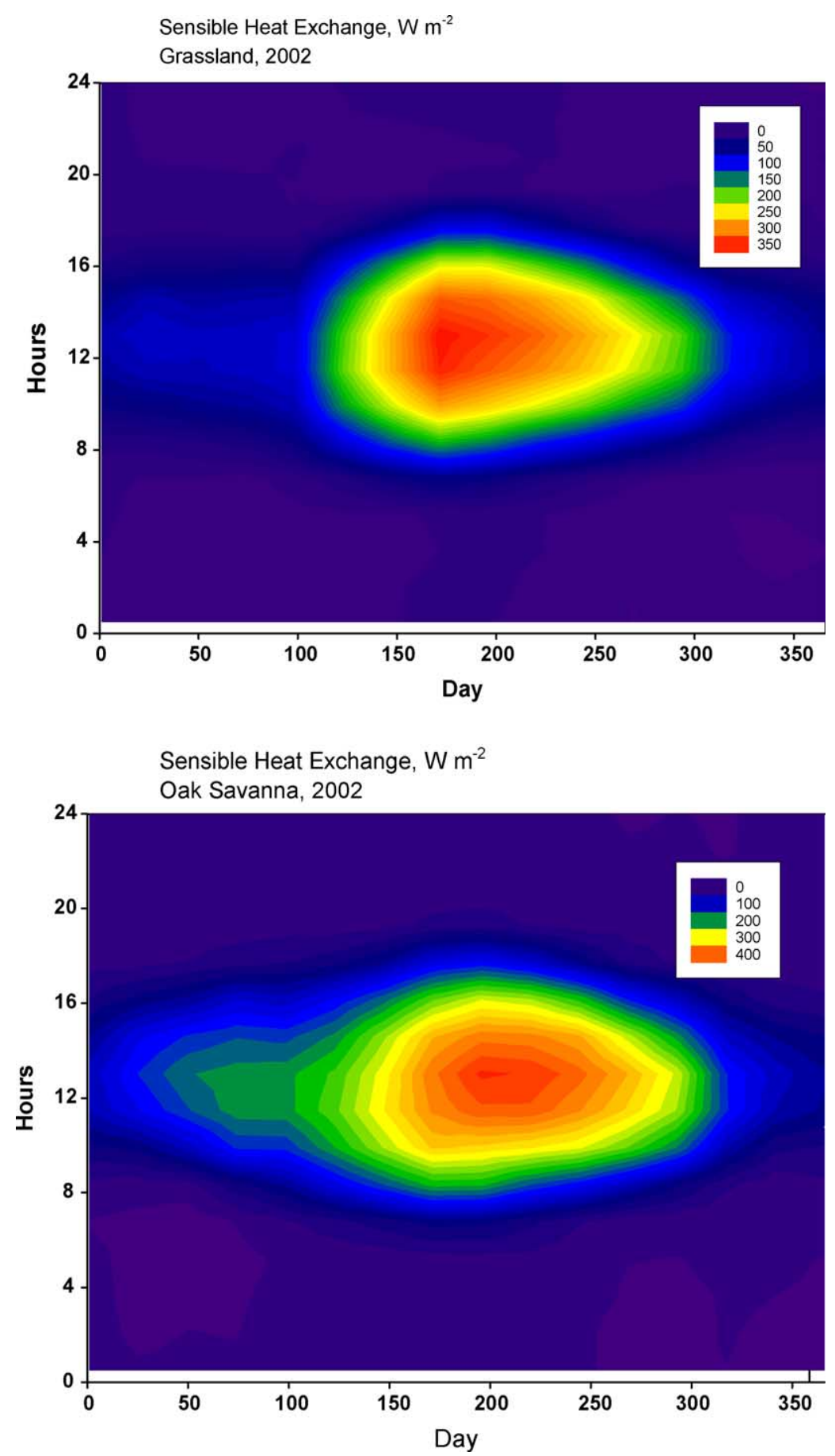

Fig. 10. Fingerprint analysis of the hourly and daily variation of sensible heat flux density at an annual grassland and an oak woodland site. The data are for the year 2002 . 


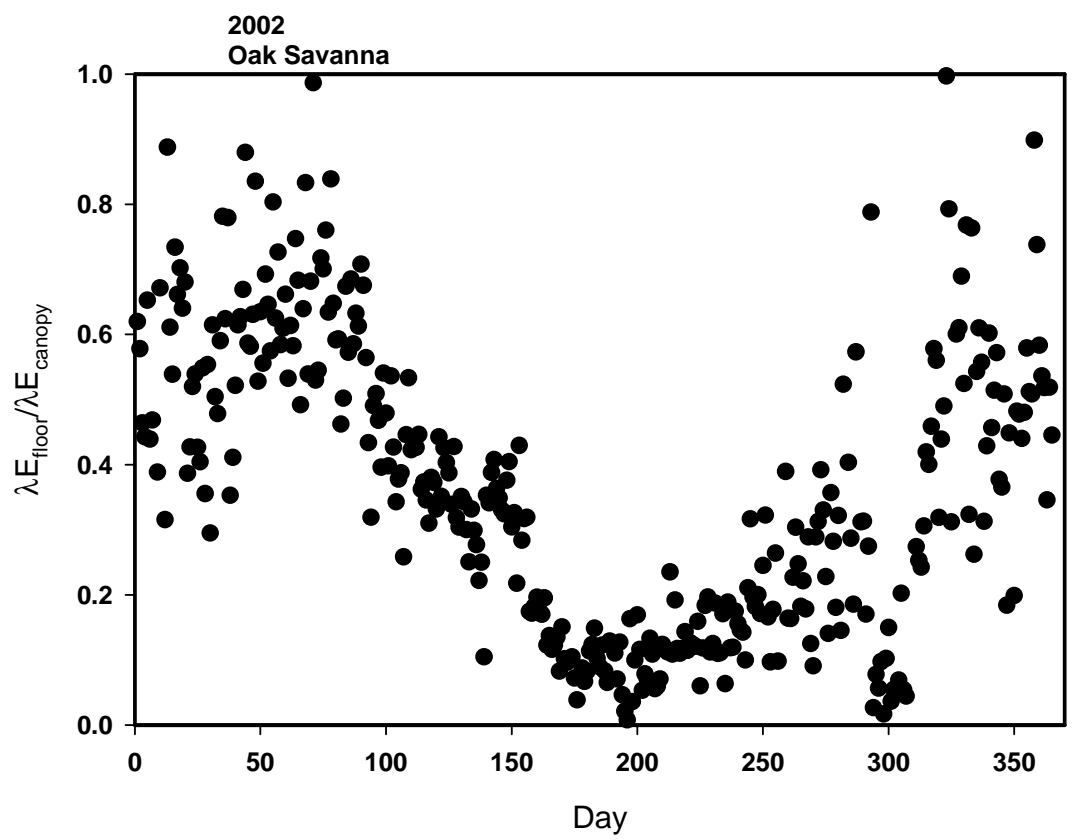

Fig. 11. Ratio of daily-integrated latent heat exchange measured under and over an oak woodland.

(Lagergren and Lindroth, 2002) than is assumed in ecohydrological models (Laio et al., 2001).

In Fig. 12, we quantify the relationship between daily-integrated latent heat flux (normalized by its equilibrium evaporation rate) with volumetric soil moisture content for the grassland and oak savanna sites. Fig. 12a shows that normalized evaporation rates from the annual grassland were constant and attained a value slightly below that of the Priestley-Taylor constant (1.26) when soil moisture was ample $\left(\theta>0.13 \mathrm{~m}^{3} \mathrm{~m}^{-3}\right)$. When volumetric water content dropped below the threshold, $0.13 \mathrm{~cm}^{3} \mathrm{~cm}^{-3}$, $\lambda E / \lambda E_{\mathrm{eq}}$ dropped precipitously and approached zero when volumetric water content in the root zone dropped to $0.05 \mathrm{~cm}^{3} \mathrm{~cm}^{-3}$. In comparison, the ratio between $\lambda E / \lambda E_{\text {eq }}$ for the tree-grass system ranged between 0.80 and 0.90 , when soil moisture was ample (Fig. 12b). This value is much below that observed for the annual grassland and is less than the equilibrium evaporation rate. This $\lambda E / \lambda E_{\mathrm{eq}}$ ratio is lower than what we measured over the grassland because peak leaf area index of the tree-grass system did not occur simultaneously with the rainy season; when the oaks were leafing out the soil was beginning to dry and the grass in the open spaces had started senescing. A break point occurs in Fig. 12b, precipitating a steep decline in $\lambda E / \lambda E_{\text {eq }}$, when the soil moisture content of the root zone was $0.15 \mathrm{~m}^{3} \mathrm{~m}^{-3}$ and the zero value for $\lambda E / \lambda E_{\mathrm{eq}}$ occurred with about $0.07 \mathrm{~m}^{3} \mathrm{~m}^{-3}$ of moisture remaining in the root zone.

The values of $\lambda E / \lambda E_{\mathrm{eq}}$, when soil moisture at the grassland site was ample, agree with measured and modeled evaporation rates from well-watered canopies of native vegetation (McNaughton and Spriggs, 1986; Baldocchi et al., 1997) and with data from another California annual grassland (Valentini et al., 1995). In contrast, Wever et al. (2002) reported that $\lambda E / \lambda E_{\text {eq }}$ of a Canadian perennial grassland was lower, ranging between 0.8 and 1.0 under ideal plant and soil conditions. With regards to relevant grassland drought studies, Hunt et al. (2002) reported that normalized evaporation of a tussock system decreased gradually as soil moisture dropped from 0.12 to $0.04 \mathrm{~m}^{3} \mathrm{~m}^{-3}$, instead of the on-off response we observed. With regards to comparative literature on $\lambda E / \lambda E_{\mathrm{eq}}$ over forests, our well-watered data agree well with measurements from over a temperate deciduous forest (Wilson et al., 2000), where $\lambda E / \lambda E_{\mathrm{eq}}$, on average, 

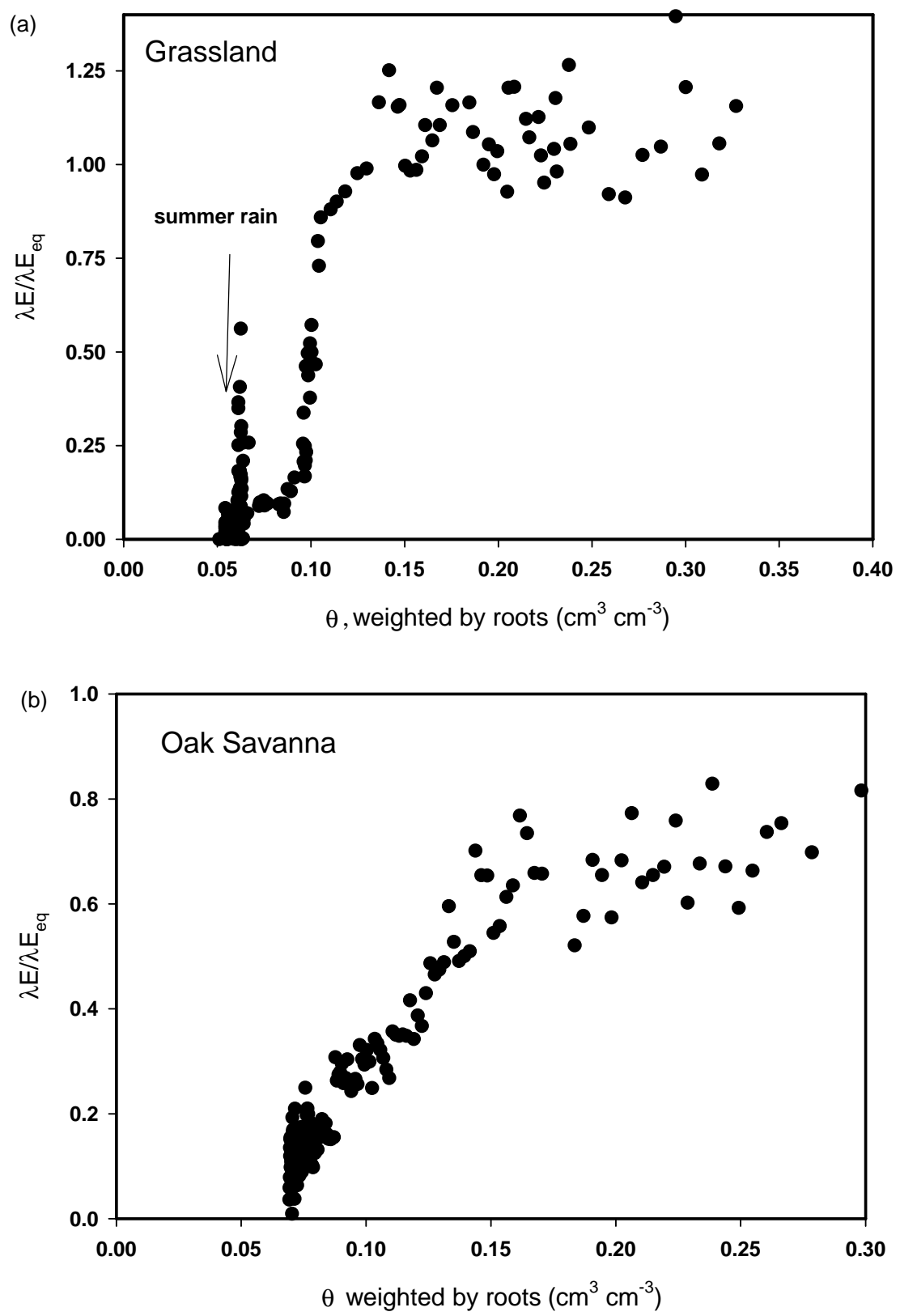

Fig. 12. Relationship between latent heat fluxes normalized by the equilibrium rate and volumetric water content. The latent heat flux ratios represent daily averages. The volumetric soil moisture measurements are weighted according to the vertical root distribution. (a) Annual grassland; (b) oak savanna. 
equals 0.70 . In contrast, slightly greater values of $\lambda E / \lambda E_{\mathrm{eq}}(0.91)$ have been reported for a boreal aspen forest (Blanken, 1997).

Many plant physiologists prefer to relate soil water deficits in terms of soil water potential $\left(\psi_{\mathrm{s}}\right)$, a thermodynamic measure of water availability (Hsiao, 1973). In Fig. 13a we plot normalized rates of evaporation from the oak savanna against two measures of soil water potential, $\psi_{\mathrm{s}}$. One measure was derived from measurements of pre-dawn leaf water potential and the other was derived by assessing $\psi_{\mathrm{s}}$ with the soil water retention curve and measurements of $\theta$ (Table 2). When canopy evaporation from the oak woodland is expressed as a function of leaf water potential, we do not observe the plateau in evaporation at the wet end of the soil moisture range, as seen in Fig. 12. Instead, $\lambda E / \lambda E_{\text {eq }}$ decreased rapidly with decreasing water potential. Two other notable observations are indicated in the data. First, low, but significant, rates of evaporation occurred when soil water potentials were as low as $-4.0 \mathrm{MPa}$, a value far below the conventional wilting point assigned for plants $(-1.5 \mathrm{MPa})$; these data support physiological evidence of the ability of blue oak to sustain physiological activity under extremely dry conditions (Griffin, 1988; Barbour and Minnich, 2000). Second, there is very good correspondence between $\lambda E / \lambda E_{\mathrm{eq}}$ and water potential, using both measures of water potential, at the low and high ends of the soil moisture range. But to achieve this level of agreement we had to sample the soil moisture profile at many depths and locations, to obtain a statistically representative value, and we had to quantify the water release curve for the soil-two pieces of information that are often missing in conventional evaporation studies.

Because predawn water potential varied in lock-step with our measurements of soil water potential in the upper 0.60 layer of the soil at the savanna site, these data suggest that few, if any, roots may have penetrated the rocky, shale layer exists below $0.60 \mathrm{~m}$. This suggestion contradicts evidence in the literature that shows that blue oak tap deep sources of water (Lewis and Burgy, 1964).

To investigate this question further we draw on other data-the change in the soil moisture after the rains ceased and the grass died. Between day 150 and 309 , we measured a loss of $48 \mathrm{~mm}$ of water from the upper $0.60 \mathrm{~m}$ layer of the soil profile. In contrast our eddy covariance measurements of evaporation indicate that $114 \mathrm{~mm}$ of water evaporated from the landscape during this period and of this total, $20 \mathrm{~mm}$ of water was lost from the dry grass layer in the understory. Based on this water budget, we conclude that $66 \mathrm{~mm}$ of water, or $57 \%$ of the total, came from other sources. We surmise that a significant fraction of moisture probably came from below the fractured shale layer, supporting the measurements of Lewis and Burgy (1964) and Sternberg et al. (1996). But we cannot discount a loss of water from the boles of the trees because we measured significant shrinkage with weekly dendrometer band measurements. Nor can we discount water coming from a reserve between $0.6 \mathrm{~m}$ and the fractured rock layer (between 0.7 and $1.0 \mathrm{~m}$ ).

To address the role of measurement errors on the assessment of the hypothesis that 'oaks tap deeper sources of water' we draw on data from the soil water balance of the dead grassland, a system with a shallow root system. In this second case, we measured a loss of $20 \mathrm{~mm}$ of water from the upper $0.60 \mathrm{~m}$ soil profile over the 145-day period dry period between days 150 and 309. In comparison we measured $29 \mathrm{~mm}$ of evaporation with the eddy covariance system. This cumulative difference of $9 \mathrm{~mm}$ represents a potential bias error with the eddy flux measurements; on a daily basis it converts to a mean evaporative flux measurement error of $0.06 \mathrm{~mm}$ per day. On an annual basis, this bias would sum to of $23 \mathrm{~mm}$, or about $6 \%$ of our annual evaporation sum; this computation assumes the soil moisture measurements were error free. And since there could have been some moisture lost from the layers below the $0.60 \mathrm{~m}$ deep soil moisture probes, the accuracy of our latent heat flux density measurements may have even been better. Hence, we conclude that our eddy covariance measurements were accurate enough to conclude that the oaks tapped some moisture sources below the top $0.60 \mathrm{~m}$ of the soil layer, as suggested by Lewis and Burgy (1964).

For the grassland, a threshold $\psi_{\mathrm{s}}$ exists for a rapid reduction in $\lambda E / \lambda E_{\mathrm{eq}}$ and it corresponds with a water potential of about $-1.5 \mathrm{MPa}$ (Fig. 13b); this value matches the conventional permanent wilting point of plants. We also observe that the null point for evaporation corresponds with soil water potentials below $-2.5 \mathrm{MPa}$. Spikes in evaporation, when the soil was driest, occurred after summer rains. These rain events wetted the grass and soil surface, but did not penetrate to the depth of the soil moisture probes. 

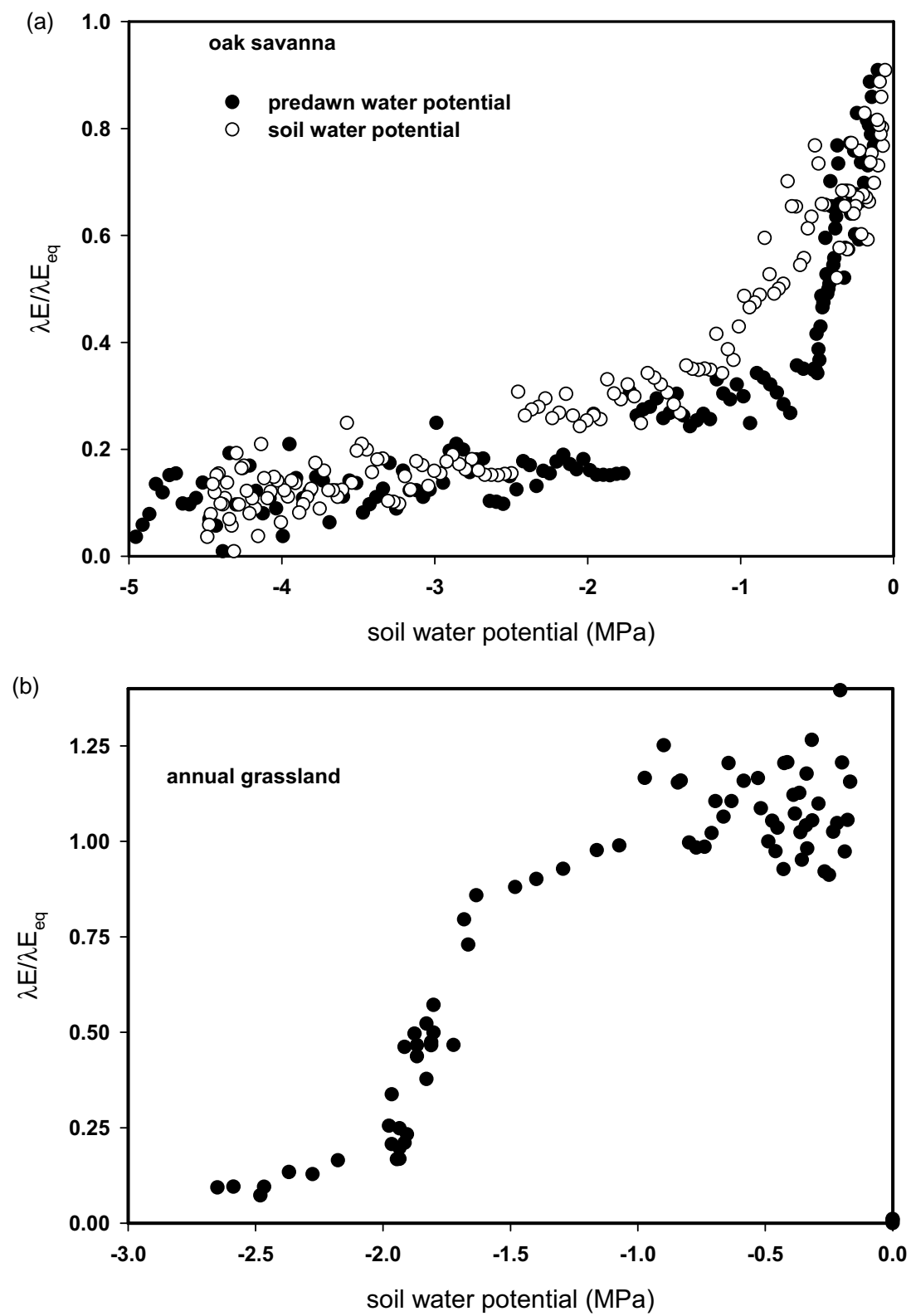

Fig. 13. The relationship between daily-integrated latent heat fluxes and soil water potential. Evaporation rates were normalized by the equilibrium values and were integrated. Pre-dawn and soil water potential were measured weekly and linear interpolations were used to fill data between days. (a) Oak savanna; (b) annual grassland. 


\subsubsection{Canopy conductance and photosynthesis}

Critical needs of global change, biogeochemical cycling and weather and climate include the quantification of parameters that define the response of stomatal conductance to soil moisture deficits. At present, the canopy conductance schemes of many land surface-atmosphere energy exchange models do not address the role of stomatal control with soil moisture deficits well, or they do so in an ad hoc manner. While this deficiency may not be consequential in humid climates, it can have significant consequences on the calculation of evaporation in semi-arid regions. For example, predictions of potential evaporation rates with radiation-based models, such as the Priestley-Taylor equation (Priestley and Taylor, 1972), severely overestimate evaporation of savanna woodlands (Major, 1988; Lewis et al., 2000). This occurs because a semi-arid climate limits the amount of leaf area that can be sustained by the ecosystem (Eagleson, 1982; Baldocchi and Meyers, 1998; Eamus and Prior, 2001; Eamus, 2003) and drying soils force stomatal closure, which limit transpiration when evaporative demand is greatest (Kelliher et al., 1993; Goulden, 1996; Kiang, 2002).

The Penman-Monteith equation (Monteith, 1981) has the potential to evaluate evaporation rates correctly, but to do so, it requires independent information on how the canopy surface conductance decreases as the soil dries, stomata close and leaf area diminishes (Kelliher et al., 1995). Over the past decade there have been successful efforts to assess stomatal conductance, independently of transpiration, by linking it to photosynthesis (Collatz et al., 1991). And by extension, several groups have proposed to quantify canopy conductance, $G_{\mathrm{c}}$, using measurements of canopy photosynthesis $\left(A_{\mathrm{c}}\right)$, relative humidity $(\mathrm{rh})$ and $\mathrm{CO}_{2}$ concentration, $C_{\mathrm{a}}$ (Valentini et al., 1995; Dolman et al., 2002; Wever et al., 2002):

$G_{\mathrm{c}} \sim \frac{A_{\mathrm{c}} \mathrm{rh}}{C_{\mathrm{a}}}+g_{0}$

In Fig. 14, we show the relationship between canopy conductance (computed by inverting the Penman-Monteith equation) and the index constructed from independent measurements of photosynthesis, $\mathrm{rh}$ and $\mathrm{CO}_{2}$. For the grassland site (Fig. 14a), this index had a slope of 9.908 and accounted for $80 \%$ of the variance of $G_{\mathrm{c}}$. Furthermore, the canopy conductance index was able to predict variations in $G_{\mathrm{c}}$ across a wide range of leaf area index and soil moisture without significant alteration of linear regression slope.

For the savanna site (Fig. 14b), a second-order polynomial regression provided a better fit through the data and accounted for $81 \%$ of the variance of $G_{\mathrm{c}}$. The slope of this regression varied from 9 to 16 as the magnitude of the $A_{\mathrm{c}} \mathrm{rh} / C_{\mathrm{a}}$ index increased from 0.001 to $0.01 \mathrm{~mol} \mathrm{~m}^{-2} \mathrm{~s}^{-1}$. In this case the slope of the regression is sensitive to changes in soil water content.

How do these results compare with others in the literature? For the grassland, the slope of the stomatal conductance index seems to be scale invariant, as it is similar to values determined for leaf-level studies on the stomatal conductance of grasslands, which range between 9 and 18 (Wohlfahrt et al., 1998). On the other hand, these data differ when compared with data from other grassland studies. Valentini et al. (1995) reported that the slope of the $G_{\mathrm{c}}$ versus $A_{\mathrm{c}} \mathrm{rh} / C_{\mathrm{a}}$ relationship ranged between 1.3 and 0.288 and decreased as soil moisture decreases; note, we converted their published data to express $G_{\mathrm{c}}$ in units of $\mathrm{mol} \mathrm{m}^{-2} \mathrm{~s}^{-1}$. But the study of Valentini et al was on a low productivity serpentine soil and the photosynthetic rates were about one-third of what we measured (Xu and Baldocchi, 2004). In the other relevant study, Wever et al. (2002) reported significant interannual variability of the stomatal conductance index for a perennial grassland-slopes ranged between 6 and 15-and they observed higher values slopes for the drier years. For the oak woodland the slope of the $G_{\mathrm{c}}$ versus $A_{\mathrm{c}} \mathrm{rh} / C_{\mathrm{a}}$ relationship is modestly approximated by leaf level value (8.8) that we observed (Xu and Baldocchi, 2003).

With the CANVEG model, we have hypothesized that $\lambda E / \lambda E_{\text {eq }}$ will scale with the product of leaf area index and maximum carboxylation velocity, $V_{\mathrm{cmax}}$, due to the links between evaporation, stomatal conductance and photosynthesis (Baldocchi and Meyers, 1998), but we have never had the data to test this hypothesis. During the summer of 2001 eddy flux measurements of $\lambda E / \lambda E_{\mathrm{eq}}$ were made coincidently with measurements of maximum carboxylation velocity, $V_{\text {cmax }}$, on leaves of blue oak (Xu and Baldocchi, 2003). To test this hypothesis, we overlay measured and computed values of $\lambda E / \lambda E_{\mathrm{eq}}$ versus the product $V_{\text {cmax }}$ times LAI in Fig. 15. Model computations corresponded well with measurements before severe 

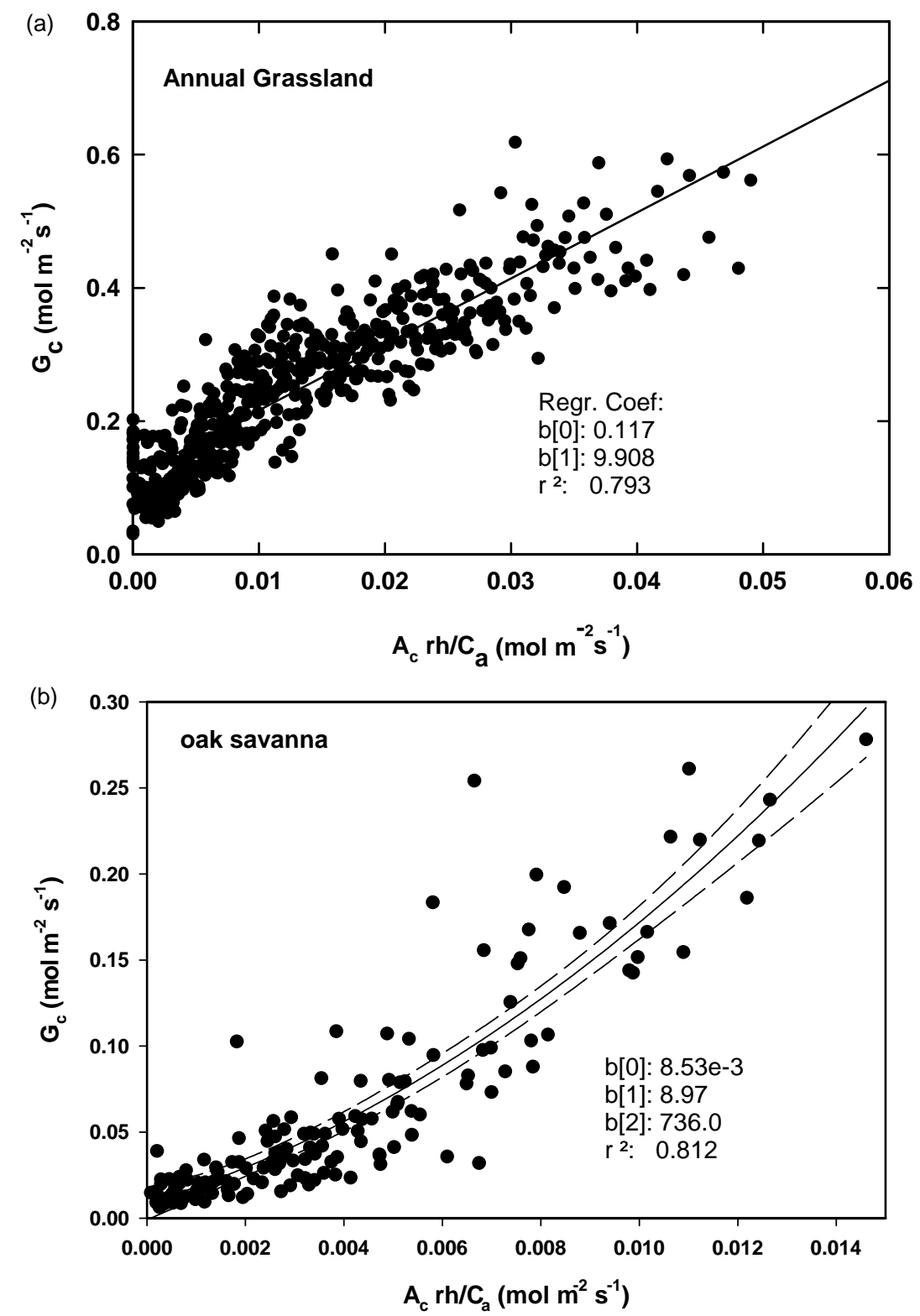

Fig. 14. The relationship between canopy conductance and an index based on canopy photosynthesis $\left(A_{\mathrm{c}}\right)$, relative humidity (rh) and $\mathrm{CO}_{2}$ concentration. Relative humidity and $\mathrm{CO}_{2}$ were weighted by solar radiation to produce a representative daily value. (a) Annual grassland site, days 60-120 for the 2001 and 2002 growing seasons. $A_{c}$ was based on measurements produced by Xu and Baldocchi (2004); (b) oak savanna, days 100-300, 2002 when trees were transpiring and understory grass was dead. $A_{\mathrm{c}}$, rh and $C_{\mathrm{a}}$ were computed on a daily-integrated time scale, to reduce sampling errors.

water deficits were established (where the independent variable ranged between 20 and 50). In addition, these theoretical calculations provide an ecophysiological explanation why $\lambda E / \lambda E_{\mathrm{eq}}$ was lower for the oak woodland, with a dead grass understory, than the green grassland-the leaf area index of the oak-savanna was lower than that of the green grassland. By late summer, soil moisture deficits had forced 


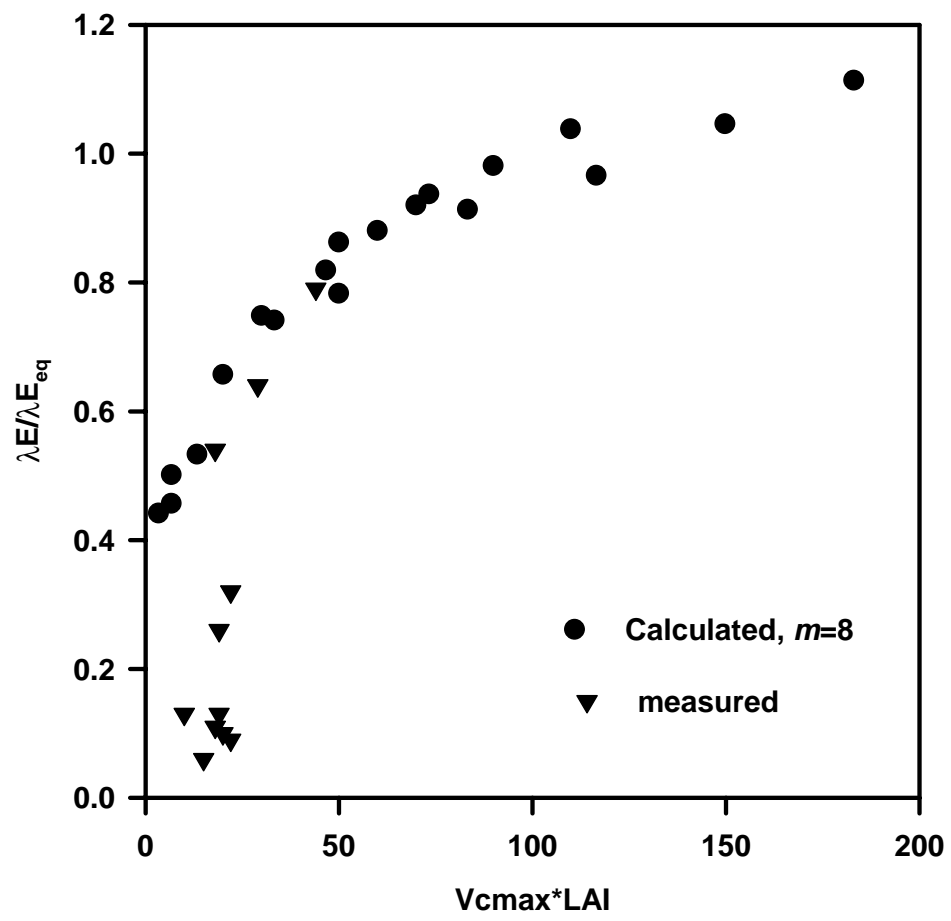

Fig. 15. Measured and calculated values of $\lambda E / \lambda E_{\text {eq }}$ plotted as a function of the product of $V_{\text {cmax }}$ and leaf area index. The model computations were derived from the CANOAK model. We assumed that the stomatal conductance coefficient, $m$, was 8 .

partial closure of the stomata, thereby causing the functional relation between modeled $\lambda E / \lambda E_{\mathrm{eq}}$ and the product, $V_{\text {cmax }}$ times LAI, to fail. These data suggest that the CANOAK model needs to be coupled to a soil moisture model to predict carbon and water fluxes for the oak savanna system during the summer drought.

\section{Conclusions}

The focus of this paper was on how a number of abiotic, biotic and edaphic factors modulate energy exchange over an oak-grass savanna and annual grassland ecosystems. The net radiation balance was greater over the oak woodland than the grassland despite the fact that both canopies received similar sums of incoming short and long wave radiation. The lower albedo and lower surface temperature of the woodland were responsible for its retainment of more energy.

The cited differences in net energy exchange had profound impacts on seasonal evaporation and sen- sible heat exchange. The woodland evaporated about $380 \mathrm{~mm}$ per year and the grassland evaporated about $300 \mathrm{~mm}$ per year. Differences in the physical water holding characteristics of the soils at the two sites account for this difference in evaporation, and provide a partial explanation why the vegetation differs at the two sites. We also report that these findings support the hypothesis that the presence of trees improve the soil water holding capacity of savanna soils (Joffre and Rambal, 1988; Jackson et al., 1990).

During the hot dry summer, when stomata were shut, sensible heat fluxes over woodland exceeded $450 \mathrm{~W} \mathrm{~m}^{-2}$ and greatly exceeded sensible heat fluxes over the grassland, which had less available energy.

On an annual basis over $36 \%$ of the soil moisture came from the understory. The measurement of water vapor fluxes above and under sparse vegetation should be a prerequisite when studying water vapor fluxes from a savanna woodland. They are needed to understand the relative controls of trees, soil and herbs on evaporation at the landscape scale. 
The response of evaporation to diminishing soil moisture was quantified using information on volumetric water content, soil water potential of the root zone and predawn water potential. When soil moisture was ample, values of latent heat exchange, normalized by the equilibrium value, $\lambda E / \lambda E_{\mathrm{eq}}$, were greater for the grassland than for the oak savanna. The grassland died and quit evaporating when the water content of the soil dropped below the permanent wilting point $(-1.5 \mathrm{MPa})$. The oak trees, on the other hand, were able to transpire, at low rates, under very dry conditions (soil water potentials down to $-4.0 \mathrm{MPa}$ ) and attain low rates of transpiration from the dry soil by tapping sources of water below the fractured shale layer. In other words, the combination of stomatal closure, the establishment of a canopy with a low leaf area index and ability of some roots to tap deep water sources provided enough water to the trees to stay alive during the harsh dry summer.

Canopy conductance of the grassland scaled with canopy photosynthesis across a wide range of leaf area indices and soil moisture. There is promise to develop algorithms that assess $G_{\mathrm{c}}$, on a regional scale, using remote sensing products that estimate GPP.

Using a coupled biophysical-ecophysiological model, CANOAK, we conclude that the combination of a low leaf area and the seasonal trend in photosynthetic capacity explained the relatively low values of $\lambda E / \lambda E_{\text {eq }}$ that were attained by the woodland.

By comparing annual evaporation, potential evaporation and precipitation we conclude that regulation of transpiration by plant functional (stomatal regulation) and structural properties (leaf area index, plant form) and life history/phenology is required to achieve a positive water balance at both sites.

\section{Acknowledgements}

This project was funded by the US Department of Energy's Terrestrial Carbon Program, grant No. DE-FG03-00ER63013, and the California Agricultural Experiment Station. These sites are members of the AmeriFlux and Fluxnet networks. We thank Mr. Russell Tonzi and Mr. and Mrs. Fran Vaira for use of their land. We thank Ted Hehn for technical assistance during this experiment and acknowledge the assistance of Dr. Lianhong Gu for installation of the grassland field site and Prof. John Battles and Dr. Randy Jackson and their students for grass inventory.

\section{References}

Baldocchi, D.D., 1997. Flux footprints under forest canopies. Boundary Layer Meteorol. 85, 273-292.

Baldocchi, D.D., 2003. Assessing the eddy covariance technique for evaluating carbon dioxide exchange rates of ecosystems: past, present and future. Global Change Biol. 9, 479-492.

Baldocchi, D., Meyers, T., 1998. On using eco-physiological, micrometeorological and biogeochemical theory to evaluate carbon dioxide, water vapor and trace gas fluxes over vegetation: a perspective. Agric. Forest Meteorol. 90 (1-2), 1-25.

Baldocchi, D.D., Vogel, C.A., Hall, B., 1997. Seasonal variation of energy and water vapor exchange rates above and below a boreal jackpine forest. J. Geophys. Res. 102, 28939-28952.

Baldocchi, D.D., Law, B.E., Anthoni, P.M., 2000. On measuring and modeling energy fluxes above the floor of a homogeneous and heterogeneous conifer forest. Agric. Forest Meteorol. 102 (2-3), 187-206.

Barbour, M., Minnich, B., 2000. California upland forests and woodlands. In: Barbour, M., Billings, W. (Eds.), North American Terrestrial Vegetation, second ed. Cambridge University Press, Cambridge, UK, pp. 161-202.

Blanken, P.D., et al., 1997. Energy balance and surface conductance of a boreal aspen forest: partitioning overstory and understory components. J. Geophys. Res. 102, 28915-28927.

Bremer, D., Auen, L., Ham, J., Owensby, C., 2001. Evaporation in a prairie ecosystem: effects of grazing by cattle. Agron. J. 93, 338-348.

Brubaker, K., Entekhabi, D., 1996. Asymmetric recovery from wet versus dry soil moisture anomalies. J. Appl. Meteorol. 35, 94-109.

Burba, G.G., Verma, S.B., 2001. Prairie growth, PAR albedo and seasonal distribution of energy fluxes. Agric. Forest Meteorol. 107 (3), 227-240.

Chehbouni, A., et al., 2000a. A preliminary synthesis of major scientific results during the SALSA program. Agric. Forest Meteorol. 105 (1-3), 311-323.

Chehbouni, A., et al., 2000b. Estimation of heat and momentum fluxes over complex terrain using a large aperture scintillometer. Agric. Forest Meteorol. 105 (1-3), 215-226.

Collatz, G.J., Ball, J.T., Grivet, C., Berry, J.A., 1991. Physiological and environmental regulation of stomatal conductance, photosynthesis and transpiration: a model that includes a laminar boundary layer. Agric. Forest Meteorol. 54 (2-4), 107136.

Constantin, J., Grelle, A., Ibrom, A., Morgenstern, K., 1999. Flux partitioning between understorey and overstorey in a boreal spruce/pine forest determined by the eddy covariance method. Agric. Forest Meteorol. 98-99, 629-643.

Dolman, A.J., Moors, E.J., Elbers, J.A., 2002. The carbon uptake of a mid latitude pine forest growing on sandy soil. Agric. Forest Meteorol. 111 (3), 157-170. 
Doran, J.C., et al., 1992. The Boardman Regional Flux Experiment. Bull. Am. Meteorol. Soc. 73, 1785-1795.

Eagleson, P.J., 1982. Ecological optimality in water limited natural soil-vegetation systems. Water Resources Res. 18, 325-340.

Eamus, D., 2003. How does ecosystem water balance affect net primary productivity of woody ecosystems? Funct. Plant Biol. 30, 187-205.

Eamus, D., Prior, L., 2001. Ecophysiology of trees of seasonally dry tropics: comparisons among phenologies. Adv. Ecol. Res. 32 (32), 113-197.

Eamus, D., Hutley, L.B., O'Grady, A.P., 2001. Daily and seasonal patterns of carbon and water fluxes above a north Australian savanna. Tree Physiol. 21 (12-13), 977-988.

Ehleringer, J., Dawson, T., 1992. Water uptake by plants: perspectives from stable isotope composition. Plant, Cell and Environ. 15, 1073-1082.

Falge, E., et al., 2001. Gap filling strategies for long term energy flux data sets, a short communication. Agric. Forest Meteorol. 107, 71-77.

Finnigan, J.J., Clement, R., Malhi, Y., Leuning, R., Cleugh, H.A., 2003. A re-evaluation of long-term flux measurement techniques part I: averaging and coordinate rotation. Boundary Layer Meteorol. 107, 1-48.

Fuchs, M., Tanner, C.B., 1967. Evaporation from a drying soil. J. Appl. Meteorol. 6, 852-857.

Goulden, M.L., 1996. Carbon assimilation and water use efficiency by neighboring Mediterranean-climate oaks that differ in water access. Tree Physiol. 16, 417-424.

Griffin, J.R., 1973. Xylem sap tension in three woodland oaks of central California. Ecology 54, 152-159.

Griffin, J.R., 1988. Oak woodland. In: Barbour, M.G., Major, J. (Eds.), Terrestrial Vegetation of California. California Native Plant Society, pp. 383-415.

Ham, J.M., Knapp, A.K., 1998. Fluxes of $\mathrm{CO}_{2}$, water vapor, and energy from a prairie ecosystem during the seasonal transition from carbon sink to carbon source. Agric. Forest Meteorol. 89 (1), 1-14.

Heady, H.F., 1988. Valley grassland. In: Barbour, M.G., Major, J. (Eds.), Terrestrial Vegetation of California. California Native Plant Society.

Higgins, S.I., Bond, W.J., Trollope, W.S.W., 2000. Fire, resprouting and variability: a recipe for grass-tree coexistence in savanna. J. Ecol. 88 (2), 213-229.

Holdridge, L.R., 1947. Determination of world plant formations from simple climatic data. Science 105, 367-368.

Hsiao, T.C., 1973. Plant responses to water stress. Ann. Rev. Plant Physiol. 24, 519-570.

Hunt, J.E., Kelliher, F.M., McSeveny, T.M., Byers, J.N., 2002. Evaporation and carbon dioxide exchange between the atmosphere and a tussock grassland during a summer drought. Agric. Forest Meteorol. 111 (1), 65-82.

Huntingford, C., Allen, S., Harding, R., 1995. An intercomparison of single and dual-source vegetation-atmosphere transfer models applied to transpiration from Sahelian savannah. Boundary Layer Meteorol. 74, 397-418.

Ishikawa, C., Bledsoe, C.S., 2000. Seasonal and diurnal patterns of soil water potential in the rhizosphere of blue oaks: evidence for hydraulic lift. Oecological.
Jackson, R.B., et al., 1996. A global analysis of root distributions for terrestrial biomes. Oecologia 108 (3), 389-411.

Jackson, L.E., Strauss, R.B., Firestone, M.K., Bartolome, J.W., 1990. Influence of tree canopies on grassland productivity and nitrogen dynamics in deciduous oak savanna. Agric., Ecosyst. Environ. 32, 89-105.

Joffre, R., Rambal, S., 1988. Soil water improvement by trees in the rangelands of southern Spain. Oecologia Plantarum 9, 405-422.

Joffre, R., Rambal, S., 1993. How tree cover influences the water balance of Mediterranean rangelands. Ecology 74, 570-582.

Joffre, R., Rambal, S., Damesin, C., 1999. Functional attributes in Mediterranean-type ecosystems. In: Pugnaire, F.I., Valladares, F. (Eds.), Handbook of Functional Plant Ecology. Marcel Dekker, New York, pp. 347-380.

Johannes, M., Knops, H., Koenig, W., 1994. Water use strategies of five sympatric species of Quercus in central coast California. Madrono 41, 290-301.

Kabat, P., Dolman, A.J., Elbers, J.A., 1997. Evaporation, sensible heat and canopy conductance of fallow savannah and patterned woodland in the Sahel. J. Hydrol. 188-189 (1-4), 494-515.

Kelliher, F.M., Leuning, R., Schulze, E.D., 1993. Evaporation and canopy characteristics of coniferous forests and grasslands. Oecologia 95 (2), 153-163.

Kelliher, F.M., Leuning, R., Raupach, M.R., Schulze, E.-D., 1995. Maximum conductances for evaporation from global vegetation types. Agric. Forest Meteorol. 73 (1-2), 1-16.

Kiang, N., 2002. Savannas and Seasonal Drought: The Landscapeleaf Connection Through Optimal Stomatal Control. University of California, Berkeley, CA, 303 pp.

Kim, J., Verma, S.B., 1990. Components of surface-energy balance in a temperate grassland ecosystem. Boundary-Layer Meteorol. 51 (4), 401-417.

Lagergren, F., Lindroth, A., 2002. Transpiration response to soil moisture in pine and spruce trees in Sweden. Agric. Forest Meteorol. 112 (2), 67-85.

Laio, F., Porporato, A., Ridolfi, L., Rodriguez-Iturbe, I., 2001. Plants in water-controlled ecosystems: active role in hydrologic processes and response to water stress. II. Probabilistic soil moisture dynamics. Adv. Water Resources 24 (7), 707-723.

Lecain, D., Morgan, J., Schuman, G., Reeder, J., Hart, R., 2000. Carbon exchange rates in grazed and ungrazed pastures of Wyoming. J. Range Sci. 53, 199-206.

Lewis, D.C., 1968. Annual hydrologic response to watershed conversion from oak woodland to annual grassland. Water Resources Res. 4, 59-72.

Lewis, D., Burgy, R.H., 1964. Relationship between oak tree roots + groundwater in fractured rock as determined by tritium tracing. J. Geophys. Res. 69, 2579.

Lewis, D., Singer, M.J., Dahlgren, R.A., Tate, K.W., 2000. Hydrology in a California oak woodland watershed: a 17 -year study. J. Hydrol. 240 (1-2), 106-117.

Lloyd, C.R., et al., 1997. A comparison of surface fluxes at the HAPEX-Sahel fallow bush sites. J. Hydrol. 189 (1-4), 400-425.

Major, J., 1988. California climate in relation to vegetation. In: Barbour, M., Major, J. (Eds.), Terrestrial Vegetation of California. Native Plant Society of California, pp. 11-74. 
McClaran, M.P., Bartolome, J.W., 1989. Effects of Quercus douglasii (Fagaceae) on herbaceous understory along a rainfall gradient. Madrono 36, 141-153.

McNaughton, S.J., 1968. Structure and function in California grasslands. Ecology 49, 962-972.

McNaughton, K.G., Spriggs, T.W., 1986. A mixed-layer model for regional evaporation. Boundary Layer Meteorol. 34 (3), 243262.

Meyers, T.P., 2001. A comparison of summertime water and CO2 fluxes over rangeland for well watered and drought conditions. Agric. Forest Meteorol. 106 (3), 205-214.

Miranda, A., et al., 1997. Fluxes of carbon, water and energy over Brazilian cerrado: an analysis using eddy covariance and stable isotopes. Plant Cell and Environ. 20, 315-328.

Monteith, J.L., 1981. Evaporation and surface-temperature. Quart. J. R. Meteorol. Soc. 107 (451), 1-27.

Moore, C.J., 1986. Frequency response corrections for eddy covariance systems. Boundary Layer Meteorol. 37, 17-35.

Moore, K.E., et al., 1996. Seasonal variation in radiative and turbulent exchange at a deciduous forest in central Massachusetts. J. Appl. Meteorol. 35 (1), 122-134.

Ohmura, A., Gilgen, H., 1993. Re-evaluation of the Global Energy Balance, Interactions Between Global Climate Subsystems, The Legacy of Hann. Geophysical Monograph. International Union of Geodesy and Geophysics, pp. 93-105.

Paw, U.K.T., Baldocchi, D.D., Meyers, T.P., Wilson, K.B., 2000. Correction of eddy covariance measurements incorporating both advectiv effects and density fluxes. Boundary Layer Meteorol. 97, 487-511.

Porporato, A., Laio, F., Ridolfi, L., Rodriguez-Iturbe, I., 2001. Plants in water-controlled ecosystems: active role in hydrologic processes and response to water stress. III. Vegetation water stress. Adv. Water Resources 24 (7), 725-744.

Priestley, C.H.B., Taylor, R.J., 1972. On the assessment of surface heat flux and evaporation using large-scale parameters. Monthly Weather Rev. 100, 81-92.

Pyles, R.D., Weare, B.C., Paw, U.K.T., Gustafson, W., 2003. Coupling between the University of California, Davis, Advanced Canopy-Atmosphere-Soil Algorithm (ACASA) and MM5: Preliminary Results for July 1998 for Western North America. J. Appl. Meteorol. 42, 557-569.

Rodriguez-Iturbe, I., D’Odorico, P., Porporato, A., Ridolfi, L., 1999a. On the spatial and temporal links between vegetation, climate, and soil moisture. Water Resources Res. 35 (12), 37093722.

Rodriguez-Iturbe, I., D’Odorico, P., Porporato, A., Ridolfi, L., 1999b. Tree-grass coexistence in savannas: the role of spatial dynamics and climate fluctuations. Geophys. Res. Lett. 26 (2), $247-250$.

Scholes, R.J., Archer, S.R., 1997. Tree-grass interactions in savannas. Annu. Rev. Ecol. Syst. 28 (1), 517-544.

Scott, R.L., et al., 2003. The understory and overstory partitioning of energy and water fluxes in an open canopy, semiarid woodland. Agric. Forest Meteorol. 114 (3-4), 127-139.

Sellers, P.J., et al., 1997. Modeling the exchanges of energy, water, and carbon between continents and the atmosphere. Science 275 (5299), 502-509.
Silberstein, R., Held, A., Hatton, T., Viney, N., Sivapalan, M., 2001. Energy balance of a natural jarrah (Eucalyptus marginata) forest in Western Australia: measurements during the spring and summer. Agric. Forest Meteorol. 109 (2), 79-104.

Stephenson, N., 1998. Actual evapotranspiration and deficit: biologically meaningful correlates of vegetation distribution across spatial scales. J. Biogeogr. 25, 855-870.

Sternberg, P.D., Anderson, M.A., Graham, R.C., Beyers, J.L., Tice, K.R., 1996. Root distribution and seasonal water status in weathered granitic bedrock under chaparral. Geoderma 72 (1-2), 89-98.

Thomas, D.S., Eamus, D., Bell, D., 1999. Optimization theory of stomatal behaviour-II. Stomatal responses of several tree species of north Australia to changes in light, soil and atmospheric water content and temperature. J. Exp. Bot. 50 (332), 393-400.

Thompson, R.S., Anderson, K.H., Bartlein, P.J., 1999. Atlas of relations between climatic parameters and distributions of important trees and shrubs in North America. Hardwoods. US Geological Survey Professional Paper 1650-B. USGS, 423 pp.

Tuzet, A., Castell, J.-F., Perrier, A., Zurfluh, O., 1997. Flux heterogeneity and evapotranspiration partitioning in a sparse canopy: the fallow savanna. J. Hydrol. 188-189 (1-4), 482493.

Unland, H.E., Houser, P.R., Shuttleworth, W.J., Zong, L.Y., 1996. Surface flux measurement and modeling at a semi-arid Sonoran Desert site. Agric. Forest Meteorol. 82 (1-4), 119-153.

Valentini, R., Gamon, J.A., Field, C.B., 1995. Ecosystem gas exchange in a California grassland: seasonal patterns and implications for scaling. Ecology 76, 1940-1952.

van Wijk, M.T., Rodriguez-Iturbe, I., 2002. Tree-grass competition in space and time: insights from a simple cellular automata model based on ecohydrological dynamics. Water Resources Res. 10.1029/2001WR000768.

Verma, S.B., Kim, J., Clement, R.J., 1989. Carbon-dioxide, water-vapor and sensible heat fluxes over a tallgrass prairie. Boundary Layer Meteorol. 46 (1-2), 53-67.

Webb, E.K., Pearman, G.I., Leuning, R., 1980. Correction of flux measurements for density effects due to heat and water-vapor transfer. Quart. J. R. Meteorol. Soc. 106 (447), 85-100.

Wever, L.A., Flanagan, L.B., Carlson, P.J., 2002. Seasonal and interannual variation in evapotranspiration, energy balance and surface conductance in a northern temperate grassland. Agric. Forest Meteorol. 112 (1), 31-49.

Wilson, K., et al., 2002. Energy balance closure at FLUXNET sites. Agric. Forest Meteorol. 113 (1-4), 223-243.

Wilson, K.B., Baldocchi, D.D., 2000. Seasonal and interannual variability of energy fluxes over a broadleaved temperate deciduous forest in North America. Agric. Forest Meteorol. 100 (1), 1-18.

Wilson, K., Hanson, P.J., Baldocchi, D.D., 2000. Evaporation and energy fluxes beneath a temperate deciduous forest in North America. Agric. Forest Meteorol. 102, 83-103.

Wohlfahrt, G., Bahn, M., Horak, I., Tappeiner, U., Cernusca, A., 1998. A nitrogen sensitive model of leaf carbon dioxide and water vapour gas exchange: application to 13 key species 
from differently managed mountain grassland ecosystems. Ecol. Modell. 113 (1-3), 179-199.

Xu, L., Baldocchi, D.D., 2003. Seasonal trend of photosynthetic parameters and stomatal conductance of blue oak (Quercus douglasii) under prolonged summer drought and high temperature. Tree Physiol. 23, 865-877.
Xu, L., Baldocchi, D.D., 2004 Seasonal variation in carbon dioxide exchange over a Mediterranean annual grassland in California. Agricultural and Forest Meteorology, (in press).

Zeng, N., Neelin, J.D., 2000. The role of vegetation-climate interaction and interannual variability in shaping the African savanna. J. Clim. 13, 2665-2669. 